\title{
Soil microbial biomass and function are altered by 12 years of crop rotation
}

\author{
Marshall D. McDaniel ${ }^{1, a}$ and A. Stuart Grandy ${ }^{1}$ \\ ${ }^{1}$ Department of Natural Resources and the Environment, University of New Hampshire, Durham, NH, USA \\ a current address: Department of Agronomy, Iowa State University, 2517 Agronomy Hall, \\ 716 Farm House Lane, Ames, IA 50011, USA \\ Correspondence to: Marshall D. McDaniel (marsh@iastate.edu)
}

Received: 31 May 2016 - Published in SOIL Discuss.: 4 July 2016

Revised: 19 September 2016 - Accepted: 8 October 2016 - Published: 2 November 2016

\begin{abstract}
Declines in plant diversity will likely reduce soil microbial biomass, alter microbial functions, and threaten the provisioning of soil ecosystem services. We examined whether increasing temporal plant biodiversity in agroecosystems (by rotating crops) can partially reverse these trends and enhance soil microbial biomass and function. We quantified seasonal patterns in soil microbial biomass, respiration rates, extracellular enzyme activity, and catabolic potential three times over one growing season in a 12-year crop rotation study at the W. K. Kellogg Biological Station LTER. Rotation treatments varied from one to five crops in a 3-year rotation cycle, but all soils were sampled under a corn year. We hypothesized that crop diversity would increase microbial biomass, activity, and catabolic evenness (a measure of functional diversity). Inorganic $\mathrm{N}$, the stoichiometry of microbial biomass and dissolved organic $\mathrm{C}$ and $\mathrm{N}$ varied seasonally, likely reflecting fluctuations in soil resources during the growing season. Soils from biodiverse cropping systems increased microbial biomass $\mathrm{C}$ by $28-112 \%$ and $\mathrm{N}$ by $18-58 \%$ compared to low-diversity systems. Rotations increased potential C mineralization by as much as $53 \%$, and potential $\mathrm{N}$ mineralization by $72 \%$, and both were related to substantially higher hydrolase and lower oxidase enzyme activities. The catabolic potential of the soil microbial community showed no, or slightly lower, catabolic evenness in more diverse rotations. However, the catabolic potential indicated that soil microbial communities were functionally distinct, and microbes from monoculture corn preferentially used simple substrates like carboxylic acids, relative to more diverse cropping systems. By isolating plant biodiversity from differences in fertilization and tillage, our study illustrates that crop biodiversity has overarching effects on soil microbial biomass and function that last throughout the growing season. In simplified agricultural systems, relatively small increases in crop diversity can have large impacts on microbial community size and function, with cover crops appearing to facilitate the largest increases.
\end{abstract}

\section{Introduction}

Research manipulating aboveground biodiversity in grasslands has shown a strong link between plant species richness and soil functions (Tilman et al., 1997; Zak et al., 2003; Eisenhauer et al., 2010; Mueller et al., 2013). While this research has contributed to our understanding of abovegroundbelowground biodiversity in natural ecosystems, it fails to capture the biodiversity dynamics in agroecosystems, where crop rotations can be used to substitute temporal for spatial biodiversity. Given that species richness at any given time in a rotated cropping system is 1 (excluding any weeds), the aboveground-belowground relationships dependent on diversity in agroecosystems and spatially diverse ecosystems (e.g., grasslands) may not be the same.

Crop rotations have been shown to have large positive effects on soil C, N, and microbial biomass (McDaniel et al., 2014a), plant pathogen suppression (Krupinsky et al., 2002), and yields (Smith et al., 2008; Riedell et al., 2009). These positive effects on crop production have been colloquially referred to as the "rotation effect". However, the mechanistic 
processes that link aboveground crop rotational diversity and belowground soil processes and contribute to the "rotation effect" remain elusive. One hypothesis explaining the benefits of crop rotations is that greater diversity of plant inputs to soil organic matter (SOM) over time enhances belowground biodiversity and soil ecosystem functioning (Hooper et al., 2000; Waldrop et al., 2006; Grandy and Robertson, 2007). Despite being low in spatial diversity, crop rotations have been shown to increase soil microbial and faunal biodiversity (Ryszkowski et al., 1998; Wu et al., 2008; Tiemann et al., 2015) and increase microbial carbon use efficiency (Kallenbach et al., 2015).

One essential function of soil microbial communities is the catabolism of newly added substrates from crops. The range and efficiency of microbial catabolism has great implications for ecosystem services such as sequestering $\mathrm{C}$ and soil fertility (Carpenter-Boggs et al., 2000; Kallenbach et al., 2015), as well as for ecosystem "dis-services" such as emission of soilto-atmosphere greenhouse gases (McDaniel et al., 2014b). Furthermore, the partitioning of resources used in catabolism of residue and formation of SOM will affect long-term soil fertility (Lange et al., 2015; Kallenbach et al., 2015).

Soil microbial catabolism can be assessed using many different methods. The two most common measures are soil extracellular enzyme activities, microbe-produced catalysts for catabolism of soil substrates, and respiration response when supplying microbes with a source of $\mathrm{C}$. The latter method, when multiple $\mathrm{C}$ compounds are added to the same soil, is commonly referred to as community-level physiological profiles (CLPPs), or as catabolic response profiles. The basic method for measuring soil CLPP involves adding a suite of $\mathrm{C}$ substrates to soils and measuring the catabolic response as $\mathrm{CO}_{2}$ production or $\mathrm{O}_{2}$ consumption with redox indicators (e.g., Biolog; Guckert et al., 1996). These C substrates are typically ecologically relevant compounds found in soils, and are intended to represent root exudates, microbial or plant cell structures, or other more-processed soil organic molecules. Other studies have used CLPPs to establish a catabolic "fingerprint" to distinguish soil microbial communities from one another by how they utilize different $C$ substrates (Lupwayi et al., 1998; McDaniel et al., 2014b). The CLPP data can also be used to derive measures of metabolic diversity including substrate-use richness or catabolic evenness.

What can catabolic potential, and even catabolic evenness, tell us about soil microbial functioning in agroecosystems? Previous studies have shown that these metabolic diversity measures are increased with agroecosystem management practices that also increase soil health, e.g., reduced tillage or crop rotations (Lupwayi et al., 1998; Degens et al., 2000). In other words, soil microbial catabolism may be a good proxy for long-term consequences of agroecosystem management practices. Given that soil microorganisms, and the resources available to them in the soil, regulate many critical processes in agroecosystems, CLPPs can provide an inte- grated measure of how management practices alter microbes and substrates available to them. Modern agriculture's use of monocultures could have unknown consequences for soil microbial catabolism, as well as related processes such as SOM mineralization, but to date the effect of rotation practices and crop diversity on soil microbial functioning remains poorly understood.

Considering a lack of understanding of how soil microbial functions are influenced by crop rotations, we sought to examine the rotation effects on soil microbial biomass and function. We measured soil microbial catabolic potential, $\mathrm{C}$ and $\mathrm{N}$ mineralization, extracellular enzyme activities, and microbial biomass three times over one growing season in a long-term crop rotation experiment at the W. K. Kellogg Biological Station (established 2000). All soils were collected during the same crop phase, allowing us to separate historical rotation from current crop effects. We hypothesized that soils under more diverse crop rotations would show greater catabolic diversity and have higher measures of soil function (enzyme activities, soil microbial biomass, potentially mineralizable $\mathrm{C}$ and $\mathrm{N}$ ). In addition, we hypothesized that crop rotation effects would vary seasonally, being greatest in the spring and lessening over the growing season with the emerging influence of the current crop. The rationale for this second hypothesis is that early in the season all soils are coming out of different crops from the previous year, but over the growing season under corn the soils will become more functionally similar as the immediate crop has greater influence. Alternatively, significant rotation $\times$ season interactions on soil microbial functioning that do not converge over the growing season point to historical effects of rotations on differences in soil microbial communities and SOM.

\section{Materials and methods}

This study was conducted in the Cropping Biodiversity Gradient Experiment (CBGE) at the W. K. Kellogg Biological Station Long-term Ecological Research site $\left(42^{\circ} 24^{\prime} \mathrm{N}, 85^{\circ} 24^{\prime} \mathrm{W}\right)$. The CBGE was established in 2000 and consists of crop rotations ranging from monocultures to a five-species rotation (http://lter.kbs.msu.edu/research/ long-term-experiments/biodiversity-gradient/). The crop rotations were repeated but with different rotation phases within all four blocks. For example, the corn-soy-wheat rotation is replicated three times within each block, but these replicates are planted to a different crop each year. The plot dimensions were $9.1 \mathrm{~m} \times 27.4 \mathrm{~m}$ and received the same chisel plow tillage to a depth of approximately $15 \mathrm{~cm}$, and received no inputs (e.g., pesticides or fertilizers) that would have confounded the treatment effects of rotation diversity (Smith et al., 2008). Mean annual temperature and precipitation at the site are $9.7^{\circ} \mathrm{C}$ and $890 \mathrm{~mm}$. The two main soil series located at the site are Kalamazoo, a fine-loamy, mixed, mesic Typic Hapludalf, and Oshtemo, a coarse- 
loamy, mixed, mesic Typic Hapludalf (KBS, 2015). Soil pH in the top $10 \mathrm{~cm}$ ranges from 4.9 to $6.1(1: 1 \mathrm{w}$ of $0.01 \mathrm{M}$ $\mathrm{CaCl}_{2}$ ).

Soils were collected from the following cropping systems: monoculture corn (Zea mays L., mC), corn-soy (Glycine max, CS), corn-soy-wheat (Triticum aestivum, CSW), cornsoy-wheat with red clover cover crop (Trifolium pratense, CSW1), and corn-soy-wheat with red clover + rye cover crops (Secale cereale, CSW2). Most of the year there was just one crop per plot, except when red clover cover crops were inter-seeded, and thus overlapped, with the cash crop at the end of the growing season, ca. October (Fig. S1 in the Supplement; Smith et al., 2008). Soil sampling took place on 27 April 2012, 19 July 2012, and 1 November 2012 - hereafter referred to as spring, summer, and autumn. Corn was planted in all plots on 11 June 2012. Three $5 \mathrm{~cm}$ diameter soil cores $(0-10 \mathrm{~cm}$ deep) were collected between rows from each plot, homogenized in the field, and then put on ice and shipped to the University of New Hampshire. In the lab, fieldmoist soils were immediately sieved using a $2 \mathrm{~mm}$ sieve. A subsample was taken from sieved soil and dried at $105^{\circ} \mathrm{C}$ to determine gravimetric water content. Water-holding capacity was determined as the water content after soils were saturated and drained for $6 \mathrm{~h}$.

\subsection{Soil carbon and nitrogen parameters}

Five $\mathrm{g}$ of field-moist soil were extracted for inorganic $\mathrm{N}$ with $40 \mathrm{~mL}$ of $0.5 \mathrm{M} \mathrm{K}_{2} \mathrm{SO}_{4}$. The soil slurries were shaken for $1 \mathrm{~h}$ before the extracts were filtered on Whatman GF/C (5) filters and filtrate frozen and stored until analysis. Soil nitrate $\left(\mathrm{NO}_{3}^{-}\right)$and ammonium $\left(\mathrm{NH}_{4}^{+}\right)$were measured using the methods detailed in McDaniel et al. (2014c). We also used the same extracts to measure dissolved organic $\mathrm{C}$ and $\mathrm{N}$ (DOC and DON). The extracts were run on a TOC-TN analyzer (TOC-V-CPN; Shimadzu Scientific Instruments Inc., Columbia, MD, USA). Total $\mathrm{C}$ and $\mathrm{N}$ were analyzed by sieving soils through $2 \mathrm{~mm}$ sieve, grinding and analyzing on an ECS 4010 CHNSO elemental analyzer (Costech Analytical Technologies, Inc., Valencia, CA).

Potential mineralization rates of $\mathrm{C}$ (PMC) and net $\mathrm{N}$ (or PMN) estimate the quantity of potentially mineralizable SOM at an optimal temperature and soil moisture, and reflect both the activity of the microbial community and availability of SOM (Paul et al., 1999; Robertson et al., 1999). These mineralization assays provide a good indicator of the potential for a soil to provide plants with N (Stanford and Smith, 1972; Robertson et al., 1999). Both PMC and PMN were measured on $10 \mathrm{~g}$ of air-dried soils in Wheaton serum vials and brought to $50 \%$ water-holding capacity, which is near optimal water content for respiration in these soils (Grandy and Robertson, 2007), and incubated for 4 months. During this 4-month period, $\mathrm{CO}_{2}$ efflux was measured on a LI-820 infrared gas analyzer (LI-COR, Lincoln, NE). Efflux was measured using the change in headspace $\mathrm{CO}_{2}$ concentration measured between two time points. Each soil efflux measurement began by aerating jars, capping, and injecting a timezero sample and then a second sample between $5 \mathrm{~h}$ and 2 days later. Efflux was calculated as the difference in $\mathrm{CO}_{2}$ concentration between the two time points divided by time. Measurements of PMC occurred more frequently at the beginning of the experiment (daily), and became less frequent toward the end (once every other week), for a total of 19 sampling events over 120 days. High-frequency measurements are required during the beginning of these incubations, when respiration rates are high, to prevent build-up of $\mathrm{CO}_{2}$ (and lack of $\mathrm{O}_{2}$ ). The PMN was assessed by extracting the inorganic $\mathrm{N}$ $\left(\mathrm{NH}_{4}^{+}+\mathrm{NO}_{3}^{-}\right)$produced at the end of the incubation, measuring it with the methods described above, then subtracting this final value from the initial inorganic $\mathrm{N}$ extracted before the incubation began.

\subsection{Soil microbial parameters}

Soil microbial biomass C (MBC) and N (MBN) were determined using the modified chloroform fumigation and extraction method (Vance et al., 1987), but modified for extraction in individual test tubes (McDaniel et al., 2014c). Briefly, two sets of fresh, sieved soil $(5 \mathrm{~g})$ were placed in $50 \mathrm{~mL}$ test tubes, and $1 \mathrm{~mL}$ of chloroform was added to one set of tubes and capped. The tubes sat overnight $(24 \mathrm{~h})$ and were then uncapped and exposed to open air in a fume hood to allow chloroform to evaporate. Soils were then extracted in the tubes with $25 \mathrm{ml}$ of $0.5 \mathrm{M} \mathrm{K}_{2} \mathrm{SO}_{4}$. The chloroformfumigated and non-fumigated extracts were run on a TOCTN analyzer (TOC-V-CPN; Shimadzu Scientific Instruments Inc., Columbia, MD, USA). We used 0.45 (Joergensen, 1996) and 0.54 (Brookes et al., 1985) for the $\mathrm{C}$ and $\mathrm{N}$ extraction efficiencies.

Soils were analyzed for eight extracellular enzyme activities (EEAs): $\beta$-1,4-glucosidase (BG), $\beta$ $\mathrm{D}-1,4$-cellobiohydrolase $(\mathrm{CBH}), \quad \beta-1,4-\mathrm{N}$-acetyl glucosaminidase (NAG), acid phosphatase (PHOS), tyrosine aminopeptidase (TAP), leucine aminopeptidase (LAP), polyphenol oxidase (PO), and peroxidase (PER). Given the large number of samples (60) and variety of measurements made at each of three sampling dates, soil EEAs were conducted on frozen samples within 4 weeks of sampling. While some studies show freezing has minor effects on EEAs (Peoples and Koide, 2012), others show no effects (Lee et al., 2007; DeForest, 2009), and we assume that any effects of freezing will be consistent among treatments. Extracellular enzyme activity assays were carried out following previously published protocols (Saiya-Cork et al., 2002; German et al., 2011), but with some modifications. Briefly, $1 \mathrm{~g}$ of soil was homogenized with a blender in $80 \mathrm{~mL}$ of sodium acetate buffer at $\mathrm{pH} 5.6$ (the average $\mathrm{pH}$ at the site). Soil slurries were pipetted into 96-well plates and then analyzed on a Synergy 2 plate reader (BioTek Instruments, Inc., Winooski, VT). For oxidoreductase enzymes, the supernatant from 
the slurry plates were pipetted into a clean plate to avoid interference with soil particles. Hydrolase assays were read at 360/40 and 460/40 fluorescence and oxidoreductases at $450 \mathrm{~nm}$ absorbance. For more details on the extracellular enzyme methods see McDaniel et al. (2014c).

Community-level physiological profiles (CLPPs) were conducted using the MicroResp ${ }^{\mathrm{TM}}$ system (Chapman et al., 2007; Zhou et al., 2012; McDaniel et al., 2014b). The MicroResp ${ }^{\mathrm{TM}}$ system allows for high-throughput measurement of soil catabolic responses to multiple $\mathrm{C}$ substrates. Each soil was loaded into 96 deep-well plates using the MicroResp ${ }^{\mathrm{TM}}$ soil dispenser, and then brought to $50 \%$ waterholding capacity. Thirty-one substrates were used at concentrations ranging from 7.5 to $30 \mathrm{mg} \mathrm{C}$ per gram of soil $\mathrm{H}_{2} \mathrm{O}$, as recommended by the MicroResp ${ }^{\mathrm{TM}}$ manual (Table $\mathrm{S} 1$ in the Supplement). Soil and substrates were combined in analytical triplicates and a $\mathrm{CO}_{2}$ detection plate (agar-containing creosol red) was immediately placed onto the deep-well plate with an air tight seal provided by the MicroResp ${ }^{\mathrm{TM}}$ kit. The soil and substrates were incubated in the dark for $6 \mathrm{~h}$ at $25^{\circ} \mathrm{C}$. The detector plate absorbencies were read at times 0 and $6 \mathrm{~h}$ at $540 \mathrm{~nm}$ on a Synergy 2 plate reader (BioTek Instruments, Inc., Winooski, VT). Absorbance data were normalized and converted to a $\mathrm{CO}_{2}$ efflux rate $\left(\mu \mathrm{g} \mathrm{CO}_{2}-\mathrm{Cg} \mathrm{soil}^{-1} \mathrm{~h}^{-1}\right)$, according to the MicroResp ${ }^{\mathrm{TM}}$ procedure (Chapman et al., 2007).

\subsection{Data analyses}

Cumulative potentially mineralizable $\mathrm{C}$ and $\mathrm{N}$ were calculated in SigmaPlot v12.5 (Systat Software, Inc., San Jose, CA) using the integration macro area below curves. Data not conforming to ANOVA assumptions of homogeneity of variances and normality were transformed before analyses (Zuur et al., 2010). Catabolic evenness (CE), a measure of substrate diversity, was calculated using the Simpson-Yule index, $\mathrm{CE}=1 / \Sigma p_{i}^{2}$, where $p_{i}$ is the proportion of a substrate respiration response to the total response induced from all substrates (Degens et al., 2000; Magurran, 2004). Metabolic quotient $\left(q \mathrm{CO}_{2}\right)$ was calculated simply as the basal respiration over $6 \mathrm{~h}$ (determined in the MicroResp ${ }^{\mathrm{TM}}$ method) divided by the MBC. Almost all the soil data were non-normal, including DOC, DON, PMC, PMN, microbial biomass, enzymes, and catabolic evenness. All these data were lognormally transformed, except for catabolic evenness, which was square-root-transformed to meet normality requirements.

Response variables were analyzed using a two-way analysis of variance (ANOVA), with season and rotation as main effects. The ANOVAs were conducted in SAS 9.3 (SAS Institute, Cary, NC) using the proc mixed function, and post hoc $t$ tests were used to determine significant differences among means using $l$ s means. Block was assigned as a random effect variable within the model. Correlations between variables were made using proc corr, and Pearson's corre- lation coefficients are reported. Model effects were deemed significant if $\alpha<0.05$.

All multivariate data analyses were performed with R software v. 3.0.0 (the R Foundation for Statistical Computing, Vienna, Austria). CLPP data were checked to ensure they conformed to principal components analysis assumptions. The prcomp function in the vegan package (Oksanen et al., 2016) was used for PCA of CLPP data. In order to correlate environmental variables with the multivariate CLPP data we used the envirfit function.

\section{Results}

It was a relatively dry year at the KBS-LTER in 2012, which had an annual precipitation of $742 \mathrm{~mm}$, compared to the historical mean of $870 \mathrm{~mm}$ (Hamilton et al., 2015). There was also an anomalous warm spell in mid- to late March (Fig. S2). After harvest, the corn yield $\left(\mathrm{kg} \mathrm{ha}^{-1} \pm \mathrm{SE}\right)$ in each treatment was as follows: $\mathrm{mC}=2846 \pm 152, \mathrm{CS}=4208 \pm 575, \mathrm{CSW}=4107 \pm 220$, $\mathrm{CSW} 1=4015 \pm 187$, and $\mathrm{CSW} 2=5219 \pm 1180 \quad(\mathrm{KBS}$, 2015).

\subsection{Soil $\mathrm{C}$ and $\mathrm{N}$ biogeochemistry}

There were few significant rotation or season effects on total soil $\mathrm{C}$ and $\mathrm{N}$, except that CSW1 had greater $\mathrm{N}$ than CSW ( $P=0.040)$, although both soil $\mathrm{C}$ and $\mathrm{N}$ tended to increase with the number of crops in rotation (Table 1). Seasonal soil $\mathrm{NO}_{3}^{-}-\mathrm{N}$ concentrations were highest in summer $(10.33 \pm 2.71)$, followed by spring $(2.98 \pm 0.69)$ and autumn $\left(1.28 \pm 0.20 \mathrm{mg} \mathrm{kg}^{-1}\right)$. Soil $\mathrm{NH}_{4}^{+}-\mathrm{N}$ was generally low, but summer had more than twice the concentrations of spring and autumn. Dissolved organic C (DOC) and N (DON) were very dynamic over the year. The DOC was highest in the autumn, while DON was over 6 times greater in the summer than the other seasons $(P<0.001)$. The mean DOC: DON in autumn was $17.4 \pm 5.9,5$ times higher than spring and 13 times higher than summer. Soil $\mathrm{NO}_{3}^{-}-\mathrm{N}$ was the only variable that showed a significant season $\times$ rotation interaction $(P<0.001)$. There were significant main effects of crop rotation on DOC and DON (Table 1). During the summer the two cover crop treatments had the highest $\mathrm{NO}_{3}^{-}-\mathrm{N}$ concentrations $\left(16.68 \pm 0.87\right.$ and $\left.12.14 \pm 4.03 \mathrm{mg} \mathrm{kg}^{-1}\right)$, which was $67 \%$ greater than CSW and CS treatments and $158 \%$ greater than $\mathrm{mC}$. The CSW1 treatment had $112 \%$ greater DOC concentrations than $\mathrm{mC}(P<0.001)$, and two cover crop treatments had $107 \%$ greater DON than non-cover-crop treatments and $211 \%$ more than the $\mathrm{mC}$ treatment.

The potentially mineralizable pools of $\mathrm{C}$ and $\mathrm{N}$ showed significant main effects of both season and rotation $(P<0.03)$, but no interactions. The PMC was highest during the autumn $\left(636 \pm 105 \mu \mathrm{gCO}_{2}-\mathrm{Cg} \mathrm{soil}^{-1}\right)$, while PMN was highest during the summer $\left(89 \pm 105 \mu \mathrm{g} \mathrm{NH}_{4}^{+}+\mathrm{NO}_{3}^{-} \mathrm{g} \mathrm{soil}^{-1}\right)$. Generally, both PMC 
Table 1. Soil carbon $(\mathrm{C})$ and nitrogen $(\mathrm{N})$ pools by season and crop rotation.

\begin{tabular}{|c|c|c|c|c|c|c|c|c|c|}
\hline Season & $\begin{array}{l}\text { Crop } \\
\text { rotation }\end{array}$ & $\begin{array}{r}\text { Total } \\
\text { organic C } \\
\mathrm{g} \mathrm{k}\end{array}$ & Total N & \multicolumn{3}{|c|}{$\mathrm{mg} \mathrm{kg}^{-1}$} & DON & $C: N$ & DOC:DON \\
\hline \multicolumn{10}{|l|}{ Spring } \\
\hline & $\mathrm{mC}$ & $8.1(0.8)$ & $0.8(0.1) \mathrm{ab}$ & $2.66(0.79)$ & $0.06(0.01) \mathrm{B}$ & 14 (4)bB & $5(1) b B$ & $9.8(0.3)$ & $2.8(0.2) \mathrm{B}$ \\
\hline & $\mathrm{CS}$ & $7.8(1.2)$ & $0.8(0.1) \mathrm{ab}$ & $2.97(1.13)$ & $0.06(0.01) \mathrm{B}$ & 11 (1)abB & $5(1) \mathrm{bB}$ & $10.3(0.4)$ & $2.1(0.2) \mathrm{B}$ \\
\hline & CSW & $7.0(0.6)$ & $0.7(0.1) \mathrm{b}$ & $2.67(0.39)$ & $0.10(0.02) \mathrm{B}$ & $21(8) a b B$ & $6(1) \mathrm{abB}$ & $10.4(0.4)$ & $4.2(1.9) \mathrm{B}$ \\
\hline & CSW1 & $8.7(0.4)$ & $0.9(0.1) \mathrm{a}$ & $3.10(0.66)$ & $0.10(0.02) \mathrm{B}$ & $44(18) a B$ & $8(1) \mathrm{aB}$ & $9.6(0.2)$ & $5.4(2.6) \mathrm{B}$ \\
\hline & CSW2 & $8.2(1.4)$ & $0.8(0.1) \mathrm{ab}$ & $3.49(0.62)$ & $0.12(0.03) \mathrm{B}$ & $26(7) \mathrm{abB}$ & $8(2) \mathrm{aB}$ & $10.2(0.2)$ & $3.3(0.4) \mathrm{B}$ \\
\hline \multicolumn{10}{|l|}{ Summer } \\
\hline & $\mathrm{mC}$ & $7.9(0.8)$ & $0.8(0.1) \mathrm{ab}$ & $5.58(0.67) \mathrm{c}$ & $0.08(0.02) \mathrm{A}$ & 35 (4)bB & $18(1) \mathrm{bA}$ & $10.2(0.4)$ & $2.0(0.1) \mathrm{C}$ \\
\hline & $\mathrm{CS}$ & $7.6(0.9)$ & $0.8(0.1) \mathrm{ab}$ & $9.47(1.96) \mathrm{b}$ & $0.08(0.01) \mathrm{A}$ & 32 (4)abB & 33 (7)bA & $9.8(0.1)$ & $1.0(0.1) \mathrm{C}$ \\
\hline & CSW & $7.6(0.7)$ & $0.8(0.0) \mathrm{b}$ & $7.76(0.75) b$ & $0.08(0.01) \mathrm{A}$ & 43 (7)abB & 28 (4)abA & $9.7(0.3)$ & $1.6(0.3) \mathrm{C}$ \\
\hline & CSW1 & $8.1(0.8)$ & $0.9(0.1) \mathrm{a}$ & $16.68(0.87) \mathrm{a}$ & $0.37(0.22) \mathrm{A}$ & $88(32) \mathrm{aB}$ & 76 (8)aA & $9.0(0.2)$ & $1.2(0.4) \mathrm{C}$ \\
\hline & CSW2 & $8.7(1.1)$ & $0.9(0.1) \mathrm{ab}$ & $12.14(4.03) \mathrm{ab}$ & $0.34(0.12) \mathrm{A}$ & 54 (7)abB & $68(13) \mathrm{aA}$ & $9.5(0.1)$ & $0.8(0.1) \mathrm{C}$ \\
\hline \multicolumn{10}{|l|}{ Autumn } \\
\hline & $\mathrm{mC}$ & $8.1(0.6)$ & $0.7(0.1) \mathrm{ab}$ & $1.31(0.15)$ & $0.07(0.02) \mathrm{B}$ & $58(21) \mathrm{bA}$ & $5(1) b B$ & $11.4(0.3)$ & 14.3 (7.3)A \\
\hline & CS & $7.7(1.1)$ & $0.7(0.1) \mathrm{ab}$ & $1.44(0.28)$ & $0.06(0.01) \mathrm{B}$ & 46 (15)abA & $5(1) \mathrm{bB}$ & $10.9(1.0)$ & $9.6(3.2) \mathrm{A}$ \\
\hline & CSW & $7.4(0.8)$ & $0.7(0.1) \mathrm{b}$ & $1.28(0.30)$ & $0.08(0.02) \mathrm{B}$ & 117(77)abA & 6 (2)abB & $10.6(0.6)$ & $15.6(5.2) \mathrm{A}$ \\
\hline & CSW1 & $9.6(0.6)$ & $0.9(0.0) \mathrm{a}$ & $1.41(0.06)$ & $0.05(0.01) \mathrm{B}$ & $102(27) \mathrm{aA}$ & $7(1) \mathrm{aB}$ & $10.6(0.5)$ & 17.1 (7.2)A \\
\hline & CSW2 & $8.9(0.9)$ & $0.9(0.1) \mathrm{ab}$ & $0.96(0.15)$ & $0.05(0.01) \mathrm{B}$ & 190 (42)abA & $6(1) \mathrm{aB}$ & $10.4(0.4)$ & 30.4 (4.0)A \\
\hline \multicolumn{2}{|c|}{ ANOVA factor } & & & & $P$ values & & & & \\
\hline \multicolumn{2}{|c|}{ Season } & 0.756 & 0.769 & $<0.001$ & 0.004 & $<0.001$ & $<0.001$ & 0.213 & $<0.001$ \\
\hline \multicolumn{2}{|c|}{ Crop rotation } & 0.298 & 0.040 & $<0.001$ & 0.084 & 0.038 & $<0.001$ & 0.223 & 0.947 \\
\hline \multicolumn{2}{|c|}{ Season $\times$ rotation } & 0.994 & 0.928 & $<0.001$ & 0.071 & 0.965 & 0.221 & 0.746 & 0.192 \\
\hline
\end{tabular}

Note: crop rotation abbreviations are monoculture corn (mC), corn-soy (CS), corn-soy-wheat (CSW), corn-soy-wheat with red clover cover crop (CSW1), and corn-soy-wheat with red clover + rye cover crops (CSW2). Means $(n=4)$ are shown with standard errors in parentheses. Significant comparisons $(P$ values in bold) are shown among rotations $($ lowercase $)$ and season (capital) with letters.

and PMN increased with increasing number of crops in rotation (Fig. 1), and the incorporation of cover crops appeared important in regulating both PMC and PMN. For example, the PMC averages of both cover crop treatments (CSW1 and CSW2) were 53 and $41 \%$ greater than $\mathrm{mC}$ and CS treatments $(P<0.042)$, respectively. The PMN average from the cover crop treatments was 36, 48, and $72 \%$ greater than the $\mathrm{mC}, \mathrm{CS}$, and CSW treatments, respectively $(P<0.015)$. The potentially mineralizable $\mathrm{C}$-to- $\mathrm{N}$ ratio $(\mathrm{PMC}: \mathrm{PMN})$, considered an index of the quality of accessible SOM (Schimel et al., 1985; Clein and Schimel, 1995), showed a significant season $\times$ rotation interaction $(P=0.045$, Fig. S3). The PMC $:$ PMN was markedly higher in the autumn than in summer and spring, indicating a greater demand for $\mathrm{N}$ in autumn. For summer and spring more diverse rotations had less $\mathrm{CO}_{2}$ produced per unit of net inorganic $\mathrm{N}$ mineralized. However, in the autumn, after harvest, the crop rotation effects on the PMC:PMN were reversed, meaning that the more diverse crop rotations had greater $\mathrm{CO}_{2}$ mineralized per unit of available $\mathrm{N}$ (Fig. S3).

\subsection{Soil microbial dynamics}

The range in soil MBC was $60-1661 \mu \mathrm{g} \mathrm{Cg} \mathrm{soil}{ }^{-1}$ across all seasons and crop rotations, but both season $(P<0.001)$ and rotation $(P=0.008)$ had significant effects on MBC (Fig. 2). Soils collected in autumn had more than twice the MBC than those collected in spring and summer. Generally, microbial biomass $\mathrm{C}$ was increased by increasing crop diversity across all seasons (Fig. 2), but only CSW1 was 112 and $28 \%$ significantly greater than $\mathrm{mC}$ and CS, respectively $(P=0.023)$. Microbial biomass $\mathrm{N}$ ranged from 6 to $61 \mu \mathrm{g} \mathrm{Ng} \mathrm{soil}{ }^{-1}$ and also showed both season $(P<0.001)$ and rotation $(P=0.005)$ effects, but no interaction. Once again, MBN generally increased with crop diversity, with the CSW (57\%), CSW1 (54\%), and CSW2 (50\%) significantly greater than the $\mathrm{mC}$ treatment $(P<0.037)$. Microbial biomass $\mathrm{C}: \mathrm{N}$ showed a significant interaction $(P=0.013)$, with more diverse cropping systems having greater MBC:MBN in summer, but not in the spring or autumn. The metabolic quotient $\left(q \mathrm{CO}_{2}\right)$ is often used as a proxy for microbial respiration efficiency (Anderson and Domsch, 1990, 2010; Wardle and Ghani, 1995). Season $(P<0.001)$ and rotation $(P=0.024)$ both influenced $q \mathrm{CO}_{2}$, with summer showing the greatest $q \mathrm{CO}_{2}(0.11 \pm 0.3)$ and autumn the lowest $(0.04 \pm 0.1) q \mathrm{CO}_{2}$. Crop diversity significantly decreased the $q \mathrm{CO}_{2}$ in the CSW1 by 40 and $48 \%$ compared to $\mathrm{mC}$ and $\mathrm{CS}$.

Soil extracellular enzymes were very dynamic over the three seasons, as evidenced by radar plots in which the 

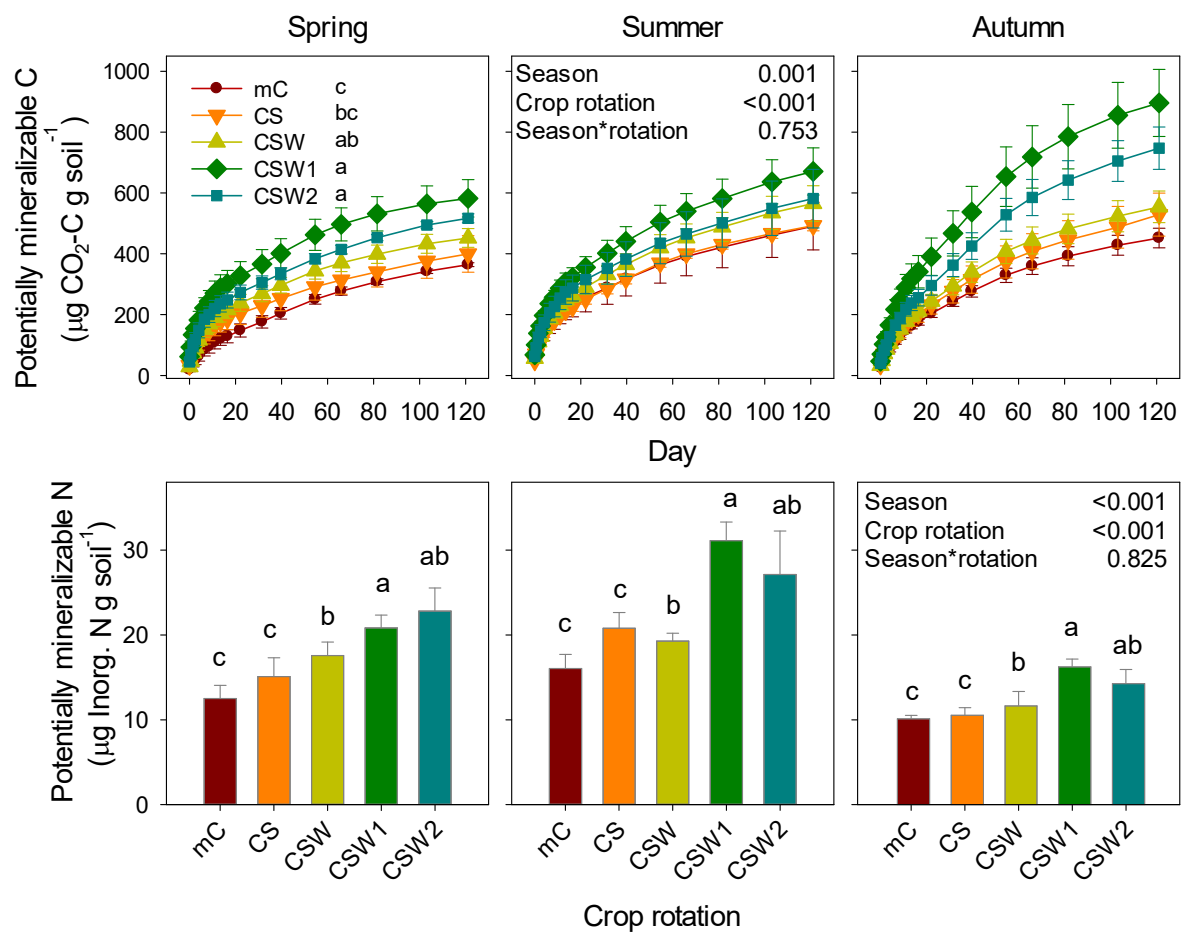

Figure 1. Potentially mineralizable carbon (top row panels) and potentially mineralizable nitrogen (bottom row panels). Crop rotation abbreviations are: monoculture corn (mC), corn-soy (CS), corn-soy-wheat (CSW), corn-soy-wheat with red clover cover crop (CSW1), and corn-soy-wheat with red clover + rye cover crops (CSW2). Means are shown and error bars are standard errors $(n=4)$. $P$ values from ANOVA results are shown for each variable with the main effects (season and crop rotation) and the interaction, as well as significant differences from post hoc results shown as lowercase letters.

area and shape for each treatment change drastically over the growing season (Fig. 3). A MANOVA with all eight EEAs showed significant season $(P<0.001)$ and rotation $(P<0.001)$ main effects, but no interaction. Most individual enzymes showed only significant rotation effects except for PO, which also showed a significant season effect, with autumn greater than the other seasons (Table 2). The soil enzyme responsible for cleaving a glucosamine from chitin (NAG) and the lignin-reducing enzyme that uses peroxide (PER) were the only enzymes that showed a significant season $\times$ rotation interaction $(P<0.001)$. Spring had the greatest activities of LAP, $175 \%$ greater than the average of the other seasons (Fig. 3, Table 2). In summer, we see a shift to the highest PHOS activity: $25 \%$ greater than autumn and $99 \%$ greater than spring. There were no main effects of season on $\mathrm{BG}$ or $\mathrm{CBH}$, but rotation main effects were significant, with the CSW1 treatment having an average of 42 and $50 \%$ higher $\mathrm{BG}$ and $\mathrm{CBH}$ activity than $\mathrm{CS}$ and $\mathrm{mC}$ soils, respectively. The majority of the hydrolase enzymes were higher in the cover crop treatments compared to that of the non-cover-crop treatments, especially $\mathrm{mC}$ (Table 2, Fig. 3). The two oxidoreductase enzymes (PO and PER) decreased with crop diversity. There were no significant main effects on the enzyme ratio used to assess $\mathrm{C}$-versus- $\mathrm{N}$ demand (BG to NAG + LAP).
The CLPP, a catabolic profile of the soil microbial communities, showed both significant season $(P<0.001)$ and rotation $(P=0.003)$ main effects (Figs. 4 and S4; Table 3). A principal components analysis of the CLPP data showed that the summer soils corresponded with highest carboxylic acid utilization (Fig. 4), as season was the strongest discriminating factor along principal component 1 (PC1, Table 3). However, when rotating and examining $\mathrm{PC} 2$ and $\mathrm{PC} 3$, there was a strong treatment gradient from the bottom-right to upperleft quadrants of the graph (Fig. 4, right panel). The lowerdiversity treatments corresponded with greater use of carboxylic acid substrates. Across seasons, summer exhibited the lowest catabolic evenness $(12.9 \pm 1.4)$, but there was no crop rotation effect on catabolic evenness using all substrates (i.e., Full, Table 4).

Due to the overwhelming influence of carboxylic acids in the PCA variation, and their possible role in abiotic reactions leading to $\mathrm{CO}_{2}$ emissions (Maire et al., 2013; Pietravalle and Aspray, 2013), we split the 31 substrates into two sets to analyze separately: (1) non-carboxylic acid substrates (a total of 21 substrates) and (2) carboxylic acids by themselves (10 substrates). Season, again, was a dominant significant effect on the MANOVAs in both groups of substrates ( $P$ values $<0.001$, Fig. S5, Tables S2 and S3). The noncarboxylic acid CLPP showed a significant treatment effect 


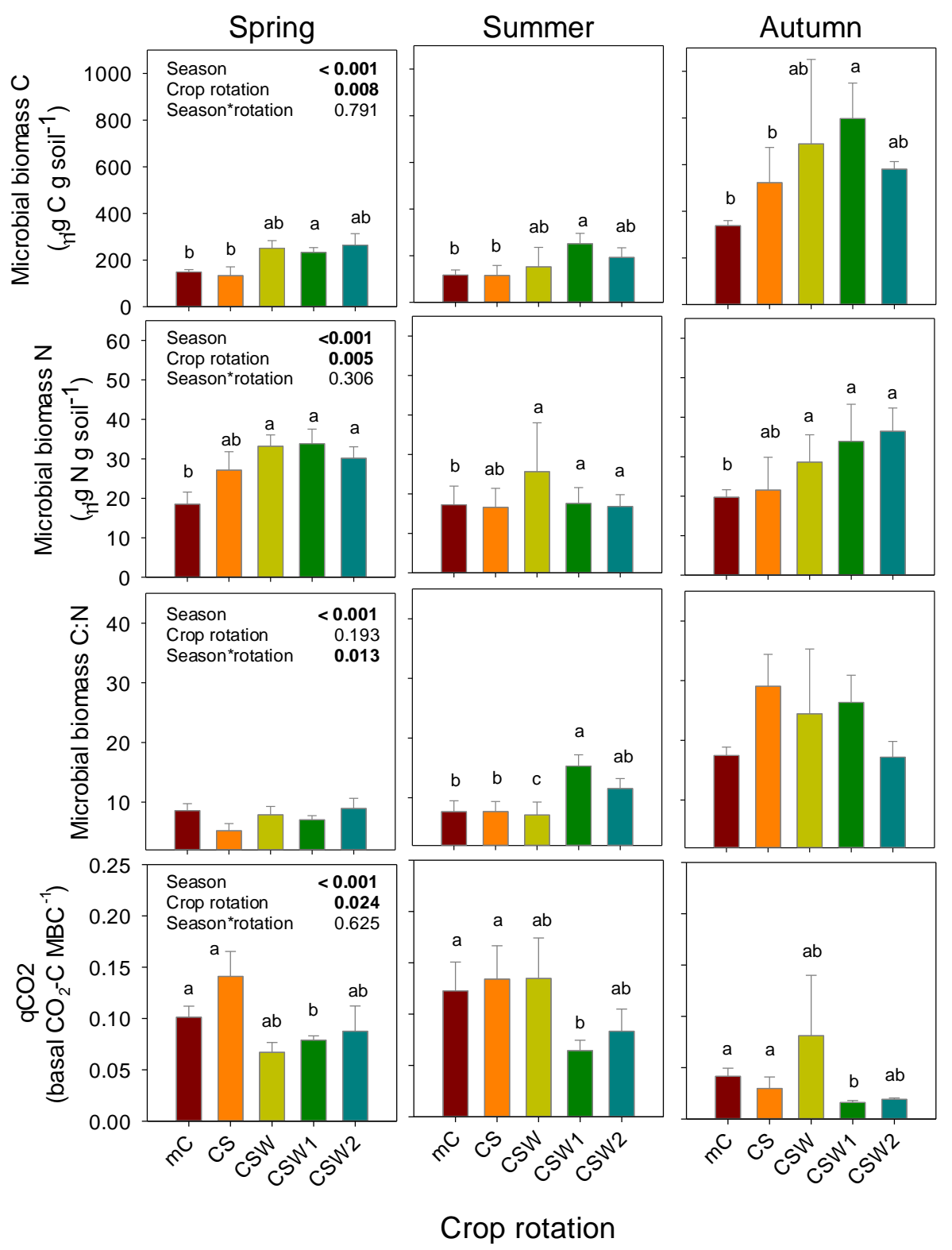

Figure 2. Soil microbial biomass parameters by season and crop rotation. See Fig. 1 for crop rotation abbreviations. Means are shown and error bars are standard errors $(n=4) . P$ values from ANOVA results are shown for each variable with the main effects (season and crop rotation) and the interaction, as well as significant differences from post hoc results shown as lowercase letters.

with $\mathrm{PC} 1$ and $\mathrm{PC} 2$, and clear separation between low- and high-diversity cropping systems $(P=0.012$, Fig. S4). The monoculture corn, as well as lower-diversity treatments, were associated with more complex substrates. In the carboxylic acid CLPP there was also a significant treatment effect, but with $\mathrm{PC} 2$ and $\mathrm{PC} 3$, and clear separation between lowand high-diversity cropping systems along PC3 $(P=0.035$, Fig. S5). The low-diversity treatments (especially monoculture corn) were more associated with simple (lower molecular weight) carboxylic acids (Cit, Mlo, and Mli) on the positive half of PC3. When carboxylic acids were split from the substrates, crop rotation had a significant effect on catabolic evenness - decreasing the catabolic evenness both within non-carboxylic acids and carboxylic acids by as much as 4 and $13 \%$, respectively (Table 4 ).

\subsection{Relationships between soil biogeochemical factors, microbial functioning and yield}

Over the three seasons many soil biogeochemical factors correlated with microbial catabolic potential, both with individual C substrate guilds and catabolic evenness (Table 5). Abiotic factors such as $\mathrm{pH}$ and sand content correlated with the 


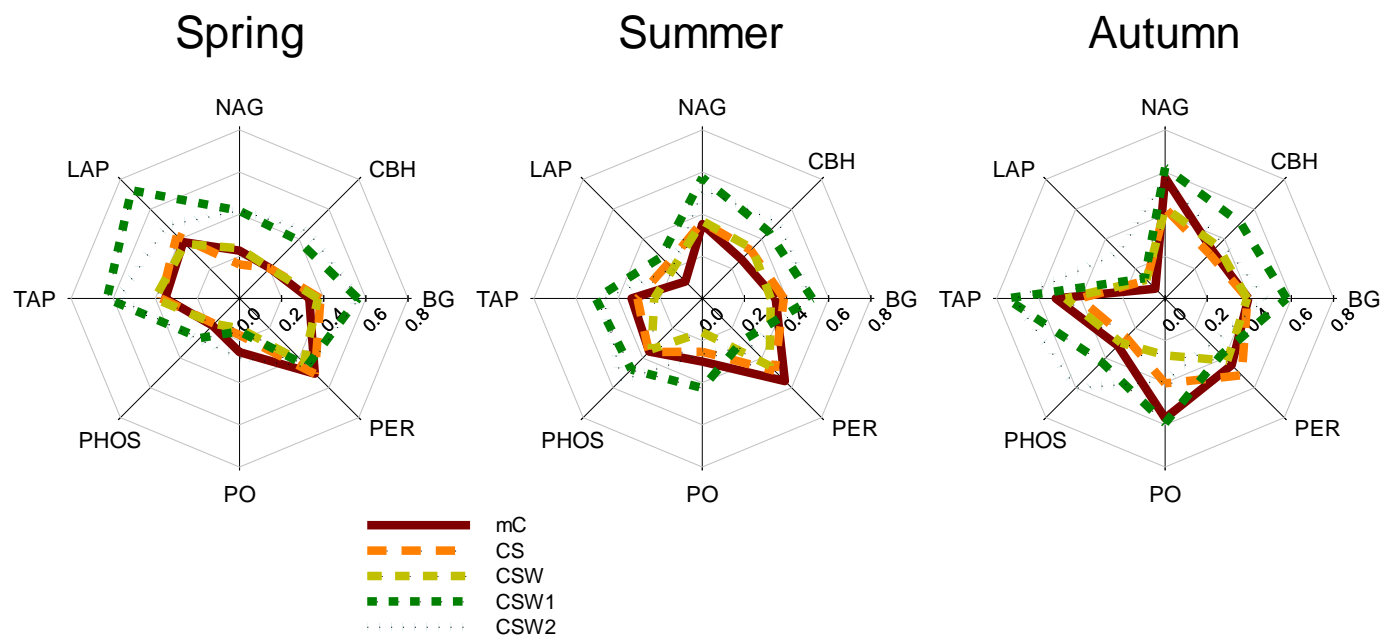

Figure 3. Mean extracellular enzyme activities (EEAs) normalized for the maximum value across all seasons. EEA abbreviations are $\beta$-1,4,-glucosidase (BG), $\beta$-D-1,4-cellobiohydrolase (CBH), $\beta$-1,4,-N-acetyl glucosaminidase (NAG), acid phosphatase (PHOS), tyrosine aminopeptidase (TAP), leucine aminopeptidase (LAP), phenol oxidase (PO), and peroxidase (PER). See Fig. 1 for crop rotation abbreviations.
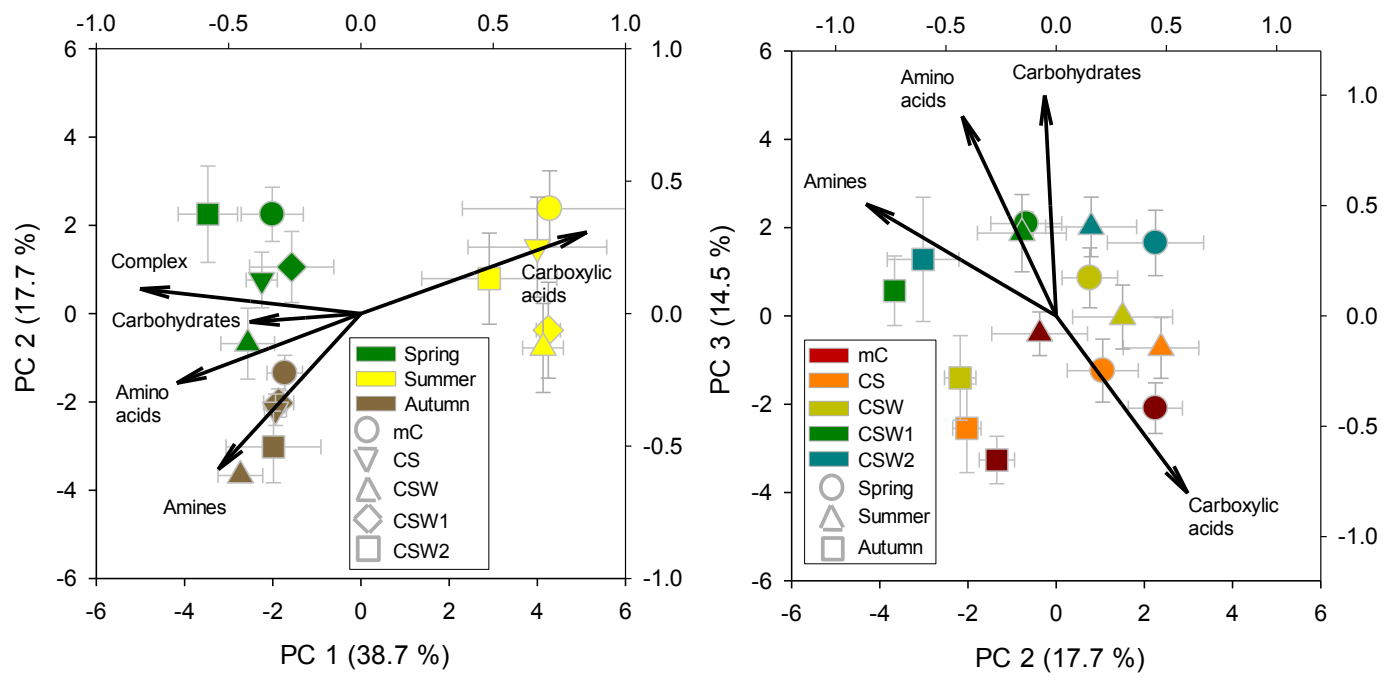

Figure 4. Principal components analysis (PCA) on the respiration response to all 31 substrates. Substrates were grouped into guilds (Table S1) which are the vectors. Left panel: principal components 1 and 2, where season is dominant discriminating factor $(P<0.001)$; right panel: principal components 2 and 3, where rotation is highlighted as a dominant discriminating factor. See also Table 5 for PCA and ANOVA results. Means are shown and error bars are standard errors $(n=4)$. See Fig. 1 for crop rotation abbreviations.

use of particular guilds of substrates. Soil $\mathrm{pH}$ positively correlated with $\mathrm{N}$-containing and complex substrates but negatively with carboxylic acids. Sand content negatively correlated with amino acids and carbohydrates but positively with carboxylic acids. The microbial response to amino acids and amines correlated best with $\mathrm{NO}_{3}^{-}-\mathrm{N}$ (Table 5) and many of the specific enzyme activities, showing negative relationships which indicated a linkage between demand for $\mathrm{N}$ and usage of N-bearing substrates. Soil $\mathrm{NO}_{3}^{-}-\mathrm{N}$ was also significantly negatively correlated with catabolic evenness.
We used the soil microbial responses of EEA and the CLPP because we assumed they would be complementary. For example, adding N-acetyl glucosamine in the CLPP should be related to $\beta$-1,4-N-acetyl glucosamindase (NAG) enzyme activity. Indeed, this was the case. Measuring NAG enzyme and adding the NAG amine to the soils showed a somewhat tight relationship, but this changed during autumn (Fig. S6). Additionally, when the CLPP substrates were grouped by guild they were significantly correlated with EEAs (Fig. S7). For instance, total amino acid catabolic response positively correlated well with LAP + TAP enzymes 
Table 2. Soil extracellular enzyme activities (EEA) expressed as nanomoles of product per hour per gram of dry soil.

\begin{tabular}{|c|c|c|c|c|c|c|c|c|c|}
\hline Season & Rotation & BGase & CBHase & LAPase & $\begin{array}{l}\text { NAGase } \\
\text { nmoll }\end{array}$ & $\begin{array}{l}\text { PHOSase } \\
-1 \mathrm{~g}^{-1} \text { soil }\end{array}$ & TAPase & PPOase & PERase \\
\hline \multicolumn{10}{|l|}{ Spring } \\
\hline & $\mathrm{mC}$ & $94(8) b$ & $27(2) b$ & $24(4) \mathrm{bA}$ & 27 (2)ab & 133 (19)bC & 10 (1)abA & 140 (47)B & 614 (12)a \\
\hline & $\mathrm{CS}$ & 107 (18)b & $28(5) \mathrm{b}$ & 28 (4)abA & $20(2) \mathrm{b}$ & $129(20) \mathrm{bC}$ & $11(0) \mathrm{abA}$ & $100(30) \mathrm{B}$ & $634(53) \mathrm{a}$ \\
\hline & CSW & 118 (12)ab & 31 (4)ab & $26(8) a b A$ & 33 (2)ab & 152 (7)abC & $12(2) \mathrm{bA}$ & $92(27) \mathrm{B}$ & 602 (59)ab \\
\hline & CSW1 & $148(5) \mathrm{a}$ & $50(5) \mathrm{a}$ & $43(5) \mathrm{abA}$ & 47 (3)a & 188 (17)aC & $16(1) \mathrm{aA}$ & 87 (13)B & $516(24) \mathrm{b}$ \\
\hline & CSW2 & 153(13)ab & $56(12) \mathrm{ab}$ & $33(5) \mathrm{aA}$ & $48(5) \mathrm{a}$ & $208(8) \mathrm{aC}$ & $16(1) \mathrm{aA}$ & 137 (61)B & $562(24) \mathrm{b}$ \\
\hline \multicolumn{10}{|l|}{ Summer } \\
\hline & $\mathrm{mC}$ & $100(5) b$ & $37(3) b$ & 7 (2)bB & $43(4)$ & $270(42) \mathrm{bA}$ & 9 (2)abB & 174 (67)B & $676(88) \mathrm{a}$ \\
\hline & $\mathrm{CS}$ & $111(17) \mathrm{b}$ & 43 (10)b & 14 (3)abB & $44(7)$ & $291(25) \mathrm{bA}$ & 9 (1)abB & 140 (50)B & $580(124) \mathrm{b}$ \\
\hline & CSW & $102(7) a b$ & 47 (12)ab & 14 (2)abB & $47(3)$ & 280 (13)abA & 7 (2)bB & 96 (29)B & $578(68) \mathrm{b}$ \\
\hline & CSW1 & $146(12) \mathrm{a}$ & 61 (10)a & 20 (3)abB & $69(10)$ & $370(45) \mathrm{aA}$ & $14(1) a B$ & 236 (91)B & $317(144) b c$ \\
\hline & CSW2 & 132 (17)ab & $62(14) \mathrm{ab}$ & $13(4) \mathrm{aB}$ & $59(9)$ & 400 (56)aA & $12(1) \mathrm{aB}$ & $126(73) \mathrm{B}$ & $392(97) \mathrm{c}$ \\
\hline \multicolumn{10}{|l|}{ Autumn } \\
\hline & $\mathrm{mC}$ & $111(9) b$ & $44(6) b$ & $5(3) \mathrm{bB}$ & $67(13)$ & $238(57) b B$ & 14 (3)abA & 330 (77)A & $543(113) \mathrm{a}$ \\
\hline & $\mathrm{CS}$ & $110(17) b$ & $42(8) b$ & 8 (1)abB & $55(7)$ & 209 (36)bB & 11 (2)abA & $234(64) \mathrm{A}$ & $461(103) b c$ \\
\hline & CSW & 115 (19)ab & 49 (15)ab & 9 (2)abB & $54(9)$ & 245 (34)abB & $14(2) \mathrm{bA}$ & $176(18) \mathrm{A}$ & $517(150) \mathrm{b}$ \\
\hline & CSW1 & $138(10) \mathrm{a}$ & $59(6) \mathrm{a}$ & 8 (1)abB & $63(13)$ & 277 (42)aB & $18(2) \mathrm{aA}$ & $300(30) \mathrm{A}$ & $396(76) c$ \\
\hline & CSW2 & 117 (15)ab & $46(8) a b$ & $17(3) \mathrm{aB}$ & $63(2)$ & $308(24) \mathrm{aB}$ & $18(2) \mathrm{aA}$ & $202(51) \mathrm{A}$ & $336(49) c$ \\
\hline \multicolumn{2}{|c|}{ ANOVA factor } & & & & $P$ values & & & & \\
\hline \multicolumn{2}{|c|}{ Season } & 0.775 & 0.063 & $<0.001$ & $<0.001$ & $<0.001$ & 0.003 & $<0.001$ & $<0.001$ \\
\hline \multicolumn{2}{|c|}{ Crop rotation } & 0.017 & 0.006 & 0.007 & $<0.001$ & 0.003 & 0.002 & 0.224 & $<0.001$ \\
\hline \multicolumn{2}{|c|}{ Season $\times$ rotation } & 0.852 & 0.839 & 0.314 & $<0.001$ & 0.967 & 0.647 & 0.837 & $<0.001$ \\
\hline
\end{tabular}

Note: see Table 1 for crop rotation abbreviations. Means $(n=4)$ are shown with standard errors in parentheses. Significant comparisons $(P$ values in bold) are shown among rotations (lowercase) and season (capital) with letters.

$\left(r^{2}=0.35, P<0.001\right)$, meaning that high activity of these enzymes in soils corresponded to high relative use of these substrates when added to soils, compared to other substrates added to the soil. This suggests that the LAP and TAP enzymes strongly reflect demand for N-bearing amino acids in soils. However, the catabolic response of the "complex" guild was negatively correlated with PO $\left(r^{2}=0.29, P<0.001\right)$. Soil PMN was better correlated with crop yields $\left(r^{2}=0.61\right.$, $P<0.001$ ) than $\mathrm{NO}_{3}^{-}$in early spring (Fig. S8), highlighting the importance of PMN-like measurements being used as soil fertility tests.

\section{Discussion}

Increasing biodiversity in this long-term crop rotation experiment has altered the soil microbial dynamics across an entire growing season. This occurred even though the soils in our study were all in the same crop phase (corn) for the season, indicating that observed differences among soils reflect long-term rotation effects. Microbial biomass $\mathrm{C}, \mathrm{N}$, potential mineralization, and catabolic potential were all altered by crop rotations, although the rotation effect for some of these indicators of microbial functioning also depends upon the season. Soil microbial biomass and activity are now widely recognized as pillars of soil health (Doran and Zeiss, 2000). Our results clearly indicate that diversifying agroecosystems (through crop rotations) enhances this aspect of soil health, and is also likely linked to changes in SOM dynamics (Tiemann et al., 2015) as well as the observed differences in yield among crop rotations (Smith et al., 2008; Fig. S8).

\subsection{Crop biodiversity and soil microbial functioning}

Both soil microbial biomass and functioning were strongly affected by increased crop diversity through rotation. This rotation effect was largely independent of the season, as indicated by the limited number of observed season $\times$ rotation interactions. The exception to this was microbial biomass $\mathrm{C} / \mathrm{N}$ ratio (Fig. 2), potentially mineralizable $\mathrm{C}$-to-N ratio (Figs. 1 and S3), and two extracellular enzyme activities (NAG and PER, Table 2), which together are likely indicative of the enhanced ability of soil microbes under diverse rotations to process, provision, and retain soil N. The stoichiometric shifts in microbial biomass and potentially mineralizable SOM suggest seasonal changes in microbial communities and/or how microbes shift between $\mathrm{C}$ and $\mathrm{N}$ resources among crop rotations. For instance, the MBC : MBN ratio is only significantly wider in the two cover crop treatments than those without 


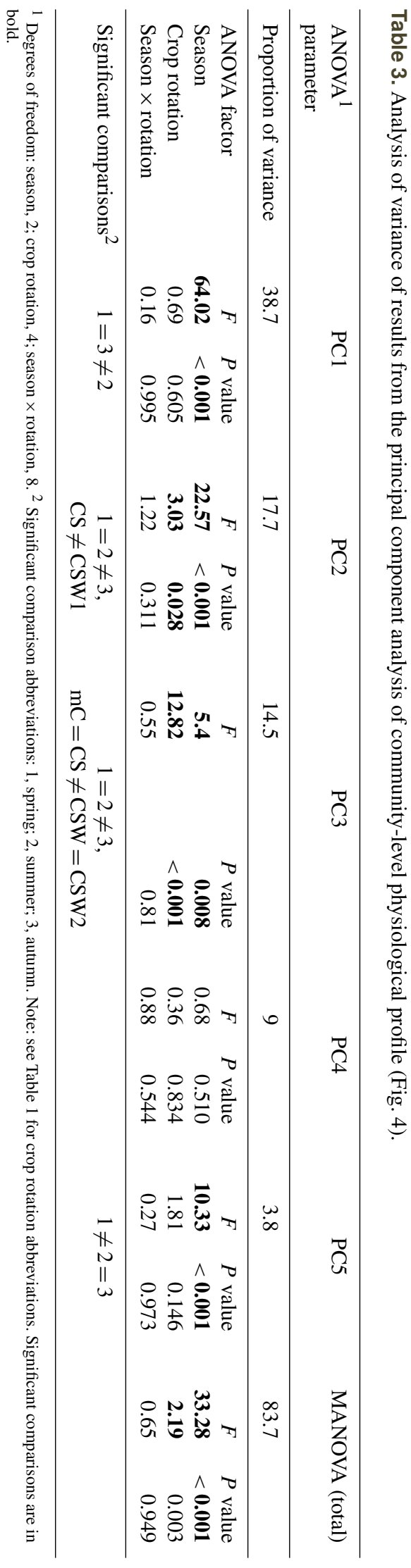

during the summer, when inorganic $\mathrm{N}$ was plentiful and labile $\mathrm{C}$ might have been limiting. On the other hand, during the autumn, when the soils were most N-limited, the potentially mineralizable $\mathrm{C}$-to- $\mathrm{N}$ ratio widened in all treatments but was widest among diverse crop rotations (Figs. 1 and S3). Together these findings suggest that labile $\mathrm{C}$ might be a major regulating factor of soil $\mathrm{N}$ cycling, and that crop rotations change these dynamics.

With regard to provisioning of $\mathrm{N}$, the PMN, MBN, and NAG enzyme activity were greater in soils under more diverse crop rotations during the spring (Figs. 1 and 2, Table 2). NAG has been shown to be strongly related to net $\mathrm{N}$ mineralization (Ekenler and Tabatabai, 2002); therefore, the alignment between these two measures of microbial function was not surprising. Taken together, though, these data indicate that soil microbes from diverse rotations might be able to better supply crops with $\mathrm{N}$ via mineralization, at this critical stage when corn crop $\mathrm{N}$ demand is high (Blackmer et al., 1989). Thus, in this severely N-limited cropping system, it makes sense that spring PMN was better related to yield than soil inorganic $\mathrm{N}$ concentrations because these crops are relying almost exclusively on SOM-derived N. Most importantly, it also suggests that the greater provisioning of $\mathrm{N}$ from SOM to plants in more diverse cropping systems is a likely factor for the higher yields in our study (Fig. S8). These findings are consistent with plant biodiversity studies that find increased aboveground diversity enhances soil microbial biomass and functioning in natural (Stephan et al., 2000; Zak et al., 2003; Lange et al., 2015) and agricultural ecosystems (Lupwayi et al., 1998; Xuan et al., 2012; McDaniel et al., 2014c).

While there were some significant differences in soil microbial dynamics between the non-cover-crop rotations (CS and CSW) and monoculture corn (Table 1, Figs. 1 and 2), the largest differences were between the two cover crop treatments and monoculture. This was particularly the case for the red-clover-only cover crop treatment (CSW1). A growing number of other studies show the large positive impact cover crops have on soil microbes and their activity (Mendes et al., 1999; Kabir and Koide, 2000; McDaniel et al., 2014c; Mbuthia et al., 2015). The reason cover crops consistently increase soil microbial biomass and activity is likely due to the increased quantity and quality of crop residue inputs, but cover crops have also been shown to improve soil physical properties that enhance biological activity (Williams and Weil, 2004; Schipanski et al., 2014). Another contributing feature of crop diversity via rotation is a greater likelihood of including "keystone" species, such as legumes like soy and red clover used in this study, which may have disproportionally large effects on soils (Wardle, 1999). While total soil $\mathrm{N}$ differences are largely undetectable, these legumes in diverse rotations are adding labile residues (including more $\mathrm{N}$ ) to these $\mathrm{N}$-limited soils, which could also be reflected in the enhanced soil microbial biomass and activity.

We hypothesized that increasing crop diversity through rotation would result in soil microbial communities that are 
Table 4. Catabolic evenness by season and crop rotation (showing full suite of C substrates, no carboxylic acids, and carboxylic acids only).

\begin{tabular}{|c|c|c|c|c|}
\hline \multirow[t]{2}{*}{ Season } & \multirow[t]{2}{*}{ Rotation } & \multicolumn{3}{|c|}{ Catabolic evenness } \\
\hline & & Full & $\begin{array}{r}\text { No carboxylic } \\
\text { acids }\end{array}$ & $\begin{array}{r}\text { Carboxylic acids } \\
\text { only }\end{array}$ \\
\hline \multicolumn{5}{|l|}{ Spring } \\
\hline & $\mathrm{mC}$ & 24.37 (0.79)A & $20.20(0.05) \mathrm{aA}$ & $7.60(0.23) \mathrm{aB}$ \\
\hline & $\mathrm{CS}$ & $23.79(0.91) \mathrm{A}$ & $19.80(0.15) \mathrm{aA}$ & $7.21(0.13) \mathrm{abB}$ \\
\hline & CSW & $22.98(0.63) \mathrm{A}$ & $19.65(0.15) \mathrm{bA}$ & $6.56(0.35) \mathrm{bB}$ \\
\hline & CSW1 & $24.28(0.44) \mathrm{A}$ & 18.95 (0.19)abA & $6.91(0.12) \mathrm{abB}$ \\
\hline & CSW2 & $24.52(0.72) \mathrm{A}$ & $19.75(0.24) \mathrm{bA}$ & $6.90(0.31) \mathrm{bB}$ \\
\hline \multicolumn{5}{|l|}{ Summer } \\
\hline & $\mathrm{mC}$ & 14.99 (1.61)B & $18.95(0.59) \mathrm{aA}$ & $4.91(0.54) \mathrm{aC}$ \\
\hline & $\mathrm{CS}$ & 12.86 (1.77)B & $20.20(0.18) \mathrm{aA}$ & $4.32(0.38) \mathrm{abC}$ \\
\hline & CSW & $12.10(1.02) \mathrm{B}$ & $19.82(0.54) \mathrm{bA}$ & $3.93(0.20) \mathrm{bC}$ \\
\hline & CSW1 & 13.83 (1.65)B & $18.59(0.83) \mathrm{abA}$ & 4.34 (0.50)abC \\
\hline & CSW2 & $12.78(0.92) \mathrm{B}$ & $19.24(0.51) \mathrm{bA}$ & $3.75(0.11) b C$ \\
\hline \multicolumn{5}{|l|}{ Autumn } \\
\hline & $\mathrm{mC}$ & $25.81(0.79) \mathrm{A}$ & $19.62(0.16) \mathrm{aB}$ & $8.47(0.24) \mathrm{aA}$ \\
\hline & $\mathrm{CS}$ & $25.82(0.55) \mathrm{A}$ & $19.11(0.22) \mathrm{aB}$ & $8.41(0.22) \mathrm{abA}$ \\
\hline & CSW & $25.71(0.74) \mathrm{A}$ & $18.98(0.28) \mathrm{bB}$ & $8.12(0.61) b A$ \\
\hline & CSW1 & $27.41(0.63) \mathrm{A}$ & $18.63(0.12) \mathrm{abB}$ & $8.90(0.24) \mathrm{abA}$ \\
\hline & CSW2 & $26.08(0.67) \mathrm{A}$ & $18.17(0.28) b B$ & $8.11(0.08) b A$ \\
\hline \multicolumn{5}{|c|}{ ANOVA factor } \\
\hline \multicolumn{2}{|c|}{ Season } & $<0.001$ & 0.002 & $<\mathbf{0 . 0 0 1}$ \\
\hline \multicolumn{2}{|c|}{ Crop rotation } & 0.357 & 0.035 & $\mathbf{0 . 0 2 8}$ \\
\hline \multicolumn{2}{|c|}{ Season $\times$ rotation } & 0.928 & 0.058 & 0.807 \\
\hline
\end{tabular}

Note: see Table 1 for crop rotation abbreviations. Means $(n=4)$ are shown with standard errors in parentheses. Significant comparisons ( $P$ values in bold) are shown among rotations (lowercase) and season (capital) with letters.

more diverse and thus would more evenly use added $\mathrm{C}$ substrates (i.e., increase catabolic evenness, or decrease the variation in use among substrates). This hypothesis stems from arguments that soil community and functional biodiversity is linked to plant biodiversity, mostly through the diversity of plant inputs to SOM (Lodge, 1997; Hooper et al., 2000; Waldrop et al., 2006; Korboulewsky et al., 2016). However, in our study, we found no evidence that crop rotational diversity increased overall soil catabolic evenness (Table 4). There is some evidence that crop rotations can alter soil bacterial catabolic diversity or the ability to use different $\mathrm{C}$ substrates (Lupwayi et al., 1998; Larkin, 2003; Govaerts et al., 2007); however, all of these studies used Biolog, which has several limitations (Preston-Mafham et al., 2002). The MicroResp ${ }^{\mathrm{TM}}$ system's main benefit is that it adds $\mathrm{C}$ substrates directly to the soil instead of transferring an inoculum from a soil slurry. The discrepancy between our study and these other studies may be due to methodological differences between Biolog and MicroResp ${ }^{\mathrm{TM}}$. Our lack of evidence for an aboveground-belowground link to catabolic potential aligns with findings from other studies that have found functional diversity measures of soil microbes are not related to plant diversity (Bartelt-Ryser et al., 2005; Jiang et al., 2012), nor plant species in general (McIntosh et al., 2013). Both Jiang et al. (2012) and McIntosh et al. (2013) used the same MicroResp ${ }^{\mathrm{TM}}$ method used in this paper, while BarteltRyser et al. (2005) used Biolog.

In our study, when a subset of the $\mathrm{C}$ substrates were analyzed (all non-carboxylic acids, or carboxylic acids only), we found that increased crop diversity decreased catabolic evenness (Table 4). This is unusual considering that soils from this same study, but collected a year prior, showed increases in soil biodiversity (Shannon-Weiner index or $H^{\prime}$ ) with increased crop diversity when measuring phospholipid fatty acids (Tiemann et al., 2015); in addition, diversity has been found to be strongly, positively related to species evenness in plants and animals (Stirling and Wilsey, 2001). In this study, our findings of a lack of an effect (or even a negative effect) of crop biodiversity on catabolic evenness is also contradictory to the findings of Degens et al. (2000), who showed that management practices that decreased soil $\mathrm{C}$ are associated with low catabolic evenness. However, evidence from these same soil samples showed that crop diversity significantly decreased $H^{\prime}$ for bacterial $16 \mathrm{~S}$ rRNA by as much as $5 \%$ 
Table 5. Pearson correlation coefficients between soil properties and community-level physiological profile (CLPP) parameters.

\begin{tabular}{|c|c|c|c|c|c|c|c|c|}
\hline \multirow[t]{2}{*}{ Soil variable } & \multicolumn{5}{|c|}{ Substrate guilds } & \multicolumn{3}{|c|}{ Catabolic evenness } \\
\hline & $\begin{array}{r}\text { Amino } \\
\text { acids }\end{array}$ & Amine & $\begin{array}{r}\text { Carboxylic } \\
\text { acids }\end{array}$ & Carbohydrates & Complex & Full & $\begin{array}{r}\text { No } \\
\text { carboxylic } \\
\text { acids }\end{array}$ & $\begin{array}{r}\text { Only } \\
\text { carboxylic } \\
\text { acids }\end{array}$ \\
\hline Water content & ns & ns & ns & ns & ns & 0.40 & ns & 0.52 \\
\hline $\mathrm{pH}$ & 0.27 & 0.43 & -0.41 & $\mathrm{~ns}$ & 0.53 & 0.68 & ns & 0.74 \\
\hline Sand & -0.36 & ns & 0.28 & -0.27 & ns & ns & ns & ns \\
\hline Silt & 0.30 & ns & ns & $\mathrm{ns}$ & ns & ns & ns & ns \\
\hline Clay & ns & ns & ns & ns & ns & ns & -0.33 & ns \\
\hline Total C & ns & ns & ns & ns & ns & ns & -0.40 & ns \\
\hline Total N & ns & ns & ns & ns & ns & ns & -0.40 & $\mathrm{~ns}$ \\
\hline C-to-N ratio & ns & 0.27 & ns & ns & 0.30 & 0.45 & ns & 0.53 \\
\hline $\mathrm{NH}_{4}^{+}$ & $\mathrm{ns}$ & -0.31 & 0.33 & ns & -0.37 & -0.40 & $\mathrm{~ns}$ & -0.38 \\
\hline $\mathrm{NO}_{3}^{-}$ & -0.58 & -0.55 & 0.66 & -0.30 & -0.72 & -0.74 & $\mathrm{~ns}$ & -0.70 \\
\hline PMC & ns & 0.29 & ns & $\mathrm{ns}$ & ns & ns & -0.63 & ns \\
\hline PMN & ns & -0.27 & 0.32 & ns & -0.55 & -0.49 & ns & -0.52 \\
\hline MBC & 0.31 & 0.49 & -0.37 & $\mathrm{~ns}$ & $\mathrm{~ns}$ & 0.41 & -0.38 & 0.47 \\
\hline $\mathrm{MBN}$ & 0.36 & 0.34 & -0.37 & 0.42 & ns & 0.36 & ns & 0.31 \\
\hline $\mathrm{MBC}: \mathrm{MBN}$ & ns & 0.40 & ns & ns & ns & 0.31 & -0.34 & 0.40 \\
\hline BGase & ns & -0.43 & 0.30 & ns & ns & -0.29 & 0.32 & -0.28 \\
\hline CBHase & -0.32 & -0.47 & 0.39 & -0.27 & ns & -0.33 & ns & -0.28 \\
\hline LAPase & ns & -0.29 & ns & ns & ns & ns & 0.49 & ns \\
\hline TAPase & ns & -0.37 & ns & ns & ns & ns & ns & 0.37 \\
\hline NAGase & -0.35 & -0.56 & 0.47 & -0.39 & -0.29 & -0.46 & 0.29 & -0.41 \\
\hline PHOSase & -0.45 & -0.66 & 0.56 & -0.46 & -0.34 & -0.63 & 0.34 & -0.60 \\
\hline PPOase & -0.38 & -0.33 & 0.37 & -0.31 & ns & ns & ns & ns \\
\hline PERase & -0.40 & -0.54 & 0.42 & -0.37 & ns & -0.30 & 0.43 & ns \\
\hline
\end{tabular}

Note: only significant correlations are shown $(P$ values $<0.05)$; bold values are $P<0.01$; ns $=$ non-significant.

compared to monoculture corn (Peralta et al., 2016). Taken together, the decrease in functional and structural diversity of soil bacteria with crop diversity indicates that crop diversity might decrease bacterial diversity in this crop rotation experiment. Nevertheless, a recent meta-analysis showed that crop rotations tend to increase soil biodiversity by $3 \%$ and richness by $15 \%$ (Venter et al., 2016), but there was large variability around these estimates. Regardless of abovegroundbelowground diversity trends, crop rotations did create functionally distinct microbial communities in our study (Fig. 4). We still do not have a good understanding of how crop rotations alter soil microbial dynamics, nor (arguably more importantly) how these changes in belowground communities might provide beneficial soil ecosystem services like increasing soil $\mathrm{C}$ or mineralizing more $\mathrm{N}$ to increase crop yields.

One trend that emerges across the suite of $31 \mathrm{C}$ substrates is that crop rotations altered soil microbial preference for $\mathrm{C}$ substrates (i.e., complex versus simple $\mathrm{C}$ substrates). The soils from monoculture corn corresponded to greater use of simple $\mathrm{C}$ substrates (especially carboxylic acids), and showed less response to the suite of $\mathrm{N}$-containing and complex substrates (Fig. 4). This finding corroborates a previous study we conducted using whole-plant residues, in which we showed diverse crop rotations resulted in greater decomposition of low-quality crop residues (e.g., corn and wheat; McDaniel et al., 2014c). Further, when looking only within the relatively labile carboxylic acid substrates, microbial communities in the less diverse crop rotations ( $\mathrm{mC}$, and to a lesser extent CS) responded to more labile, low-molecular-weight carboxylic acids (e.g., citric, malonic, and malic acid), while soil microbes from more diverse crop rotations responded more to complex, higher-molecular-weight carboxylic acids (e.g., caffeic, tartaric, and vanillic acids - Fig. S5d). The strong effects of crop diversity on catabolism of carboxylic acids is not surprising due to the small, yet dynamic, pool of these compounds in soil (Strobel, 2001). Since soil microbial function (as measured by CLPP) is an aggregate measure of both the community composition and available resources, it is impossible to tease out which (or both) have changed due to increased crop biodiversity. However, our overall findings indicate that increased aboveground biodiversity through crop rotations and cover crops appears to facilitate soil microbial communities' use of complex C substrates relative to simple ones. 


\subsection{Seasonal dynamics and $\mathrm{N}$ limitation}

Season strongly influenced the measured pools of labile C and $\mathrm{N}$ (Table 1), as well as the microbial biomass size and functioning within this agroecosystem (Figs. 1-4). We hypothesized that soil microbial function would converge over the growing season, as the current crop exerted greater influence over soil microbes. We did find some support for this hypothesis. Both multivariate measures of extracellular enzyme activities and CLPP showed treatments becoming more similar over the growing season (Figs. 3 and 4). This is based on three time points, however, and we do not know for sure whether this convergence was due to the influence of the corn crop or other factors (like microclimatic). Some studies have shown that the current plant species identity often trumps biodiversity legacy in controlling belowground microbial structure and functioning (Stephan et al., 2000; Wardle et al., 2003; Bartelt-Ryser et al., 2005). Conversely, several studies have pointed to weak or no influence of current plant species on soil microbial structure and functioning (Costa et al., 2006; Kielak et al., 2008). The question of whether plant species identity versus spatial and temporal diversity has a stronger control on soil biota remains a critical question in terrestrial ecology.

The greatest microbial biomass and activity occurred in autumn, but potential $\mathrm{N}$ mineralization peaked in summer. In perennial and annual cropping systems in Iowa, potentially mineralizable $\mathrm{N}$ declined from spring to late summer; in addition, extracellular enzyme activities peaked in July, but there was little effect of the cropping system (Hargreaves and Hofmockel, 2014). In another study, season was shown to affect microbial biomass and potentially mineralizable $\mathrm{C}$ and $\mathrm{N}$ pools in a wheat-sorghum-soybean rotation in southcentral Texas (Franzluebbers et al., 1994, 1995; Franzluebbers, 2002), but timing for peak values differed depending on the study and cropping systems, likely reflecting different climates and soil types. The frequently observed late-summer spike in microbial biomass and activity may be related to higher temperatures during this time period; however, even within agroecosystems, the timing for maximal microbial biomass varies substantially, although few microbial biomass maxima are reported in winter (Wardle, 1992). Our findings highlight the dynamic nature of soil microbial biomass and activity, especially with regard to the supply and demand of $\mathrm{N}$ (e.g., microbial $\mathrm{C}: \mathrm{N}$, substrate utilization, and extracellular enzyme activities), which is likely a limiting nutrient in these agroecosystems that are receiving no exogenous $\mathrm{N}$ inputs.

The summer warrants discussion because the sample was collected after a prolonged period of hot and dry days, but right after a large rainfall event. This rainfall event $\left(>18 \mathrm{~mm} \mathrm{day}^{-1}\right.$, Fig. S2) increased the volumetric water content in the $0-10 \mathrm{~cm}$ of a nearby soil by over $54 \%$ from the lowest value of the year $\left(0.1 \mathrm{~m} \mathrm{~m}^{-3}\right.$, data shared from Hamilton et al., 2015), and we know from previous research that drying-wetting cycles are important soil biogeochemical drivers (Borken and Matzner, 2009) and can alter microbial structure and functioning (Fierer et al., 2003; Schimel et al., 2007; Tiemann and Billings, 2011; McDaniel et al., 2014b). Indeed, the summer showed several signs of the soil microbial community being impacted by a rapid dry-wet event: lower overall microbial biomass $\mathrm{C}$, high $\mathrm{NO}_{3}^{-}-\mathrm{N}$ concentrations (Table 1), high potential N mineralization (Fig. 1), high extracellular enzyme activities per unit of microbial biomass (Fig. S9, presumably a result of lysed intracellular enzymes; Burns et al., 2013), and the particularly strong response of the summer soils to carboxylic acids (a highly labile class of compounds used by fast-growing, opportunistic microbes that would be found after a disturbance such as a dry-wet event, Figs. 4 and S3). Dry-wet cycles may drive microbial C and $\mathrm{N}$ to be reallocated to stress-response compounds instead of growth or reproduction, making $\mathrm{C}$ and $\mathrm{N}$ more vulnerable to loss from soils (Schimel et al., 2007). We captured one of these dry-wet events during one of the driest summers in the Kellogg Biological Station LTER's history and we show high soil inorganic $\mathrm{N}$ concentrations and altered microbial dynamics relative to the other dates. Climate change may increase the frequency and magnitude of these rapid dry-wet cycles (Groffman et al., 2001; McDaniel et al., 2014d) and thus may have long-term impacts on soil microbial functioning and biogeochemistry.

In the autumn we found several lines of evidence that indicate soil microbes are $\mathrm{N}$, rather than $\mathrm{C}$, limited. These lines of evidence include: lowest soil inorganic $\mathrm{N}$ concentrations, low potentially mineralizable $\mathrm{N}$, high-microbialbiomass $\mathrm{C}: \mathrm{N}$ and DOC : DON ratios, high TAP and NAG enzymes relative to other enzymes (although interestingly not LAP), and finally strong respiration response to the addition of amines and amino acids (Fig. 4). The unusually wide microbial biomass $\mathrm{C}: \mathrm{N}$ in autumn was very surprising (mean of 24 vs. 10 and 8 in spring and summer, respectively), but microbial biomass $\mathrm{C}: \mathrm{N}$ has been known to be as high as 30 in laboratory conditions (Schimel et al., 1989). Additionally, the few days before and after the collection of the autumn sample were unusually cold (Fig. S2), and cold temperatures and freezing can cause accumulation of carbohydrates in fungi (Tibbett et al., 2002), which could also widen $t$ he microbial $\mathrm{C}: \mathrm{N}$ ratio. While environmental conditions may be a factor in the microbial biomass $\mathrm{C}: \mathrm{N}$, it is likely that $\mathrm{N}$ limitation is a major factor in these long-term, unfertilized, agroecosystems.

\section{Conclusions}

As the growing population is increasingly reliant on soils for food, fiber, and fuel, we will either need to consume less, put more land into production, or better use the land we already have in production. Putting more land in production will likely result in declines in local and global biodiver- 
sity. Thus, it is critical to incorporate biodiversity through any means possible into the existing managed ecosystems even including biodiversity through time as with crop rotations. Here we show that both microbial biomass and function are strongly influenced by cropping diversity. In fact, the influence of crop rotations on soil microbes and functioning lasts over an entire growing season and even when all soils are under the same crop. Crop rotations clearly enhance soil microbial biomass and activity, which are now considered a pillar of soil health, and it appears from our study that rotations also facilitate microbes in supplying more soil $\mathrm{N}$ to crops (Fig. S8). Overall, our study highlights the importance of incorporating biodiversity into agroecosystems by including more crops in rotation, especially cover crops, to enhance beneficial soil processes controlled by soil microbes.

\section{Data availability}

Core data will be made available at the Kellogg Biological Station Long-term Ecological Research website (http: //lter.kbs.msu.edu/datatables). Otherwise, interested parties may email the corresponding author for data sets.

\section{The Supplement related to this article is available online at doi:10.5194/soil-2-583-2016-supplement.}

Acknowledgements. Support for this research was also provided by the NSF Long-Term Ecological Research Program (DEB 1027253) at the Kellogg Biological Station and by Michigan State University AgBioResearch. We are grateful for financial support from the United States Department of Agriculture (USDA) Soil Processes Program, grant \#2009-65107-05961. Also, financial support came from USDA grant \#2015-42247-519119. We would like to acknowledge both Kay Gross and Phil Robertson, who originally established these sites and have kindly provided our research team with access to them. Thanks to Stephen Hamilton and co-authors who provided soil microclimate data from a nearby experiment. Also, we would like to thank Serita Frey for helpful advice dealing with the CLPP data, and Christopher Fernandez for giving feedback on an early draft of the manuscript. Finally, we would like to thank the three anonymous reviewers, whose very valuable feedback improved the quality of this manuscript.

Edited by: E. Bach

Reviewed by: three anonymous referees

\section{References}

Anderson, T. H. and Domsch, K. H.: Application of ecophysiological quotients $\left(q \mathrm{CO}_{2}\right.$ and $\left.q \mathrm{D}\right)$ on microbial biomasses from soils of different cropping histories, Soil Biol. Biochem., 22, 251-255, 1990.

Anderson, T. H. and Domsch, K. H.: Soil microbial biomass: The eco-physiological approach, Soil Biol. Biochem., 42, 20392043, 2010.
Bartelt-Ryser, J., Joshi, J., Schmid, B., Brandl, H., and Balser, T.: Soil feedbacks of plant diversity on soil microbial communities and subsequent plant growth, Perspect. Plant Ecol. 7, 27-49, 2005.

Blackmer, A. M., Pottker, D., Cerrato, M. E., and Webb, J.: Correlations between soil nitrate concentrations in late spring and corn yields in Iowa, J. Prod. Agr., 2, 103-109, 1989.

Borken, W. and Matzner, E.: Reappraisal of drying and wetting effects on $\mathrm{C}$ and $\mathrm{N}$ mineralization and fluxes in soils, Global Change Biol., 15, 808-824, 2009.

Brookes, P. C., Landman, A., Pruden, G., and Jenkinson, D. S.: Chloroform fumigation and the release of soil nitrogen: A rapid direct extraction method to measure microbial biomass nitrogen in soil, Soil Biol. Biochem., 17, 837-842, 1985.

Burns, R. G., DeForest, J. L., Marxsen, J., Sinsabaugh, R. L., Stromberger, M. E., Wallenstein, M. D., Weintraub, M. N., and Zoppini, A.: Soil enzymes in a changing environment: Current knowledge and future directions, Soil Biol. Biochem., 58, 216234, 2013.

Carpenter-Boggs, L., Picul Jr., J. L., Vigil, M. F., and Riedell, W. E.: Soil nitrogen mineralization influenced by crop rotation and nitrogen fertilization, Soil Sci. Soc. Am. J., 64, 2038-2045, 2000.

Chapman, S., Campbell, C., and Artz, R.: Assessing CLPPs using MicroResp ${ }^{\text {TM }}$, J. Soils Sediments, 7, 406-410, 2007.

Clein, J. S. and Schimel, J. P.: Nitrogen turnover and availability during succession from alder to poplar in Alaskan taiga forests, Soil Biol. Biochem., 27, 743-752, 1995.

Costa, R., Götz, M., Mrotzek, N., Lottmann, J., Berg, G., and Smalla, K.: Effects of site and plant species on rhizosphere community structure as revealed by molecular analysis of microbial guilds, FEMS Microbiol. Ecol., 56, 236-249, 2006.

DeForest, J. L.: The influcence of time, storage temperature, and substrate age on potential soil enzyme activity in acidic forest soils using MUB-linked substrates and 1-DOPA, Soil Biol Biochem., 41, 1180-1186, 2009.

Degens, B. P., Schipper, L. A., Sparling, G. P., and VojvodicVukovic, M.: Decreases in organic C reserves in soils can reduce the catabolic diversity of soil microbial communities, Soil Biol. Biochem., 32, 189-196, 2000.

Doran, J. W. and Zeiss, M. R.: Soil health and sustainability: managing the biotic component of soil quality, Appl. Soil Ecol., 15, 3-11, 2000.

Eisenhauer, N., Beßler, H., Engels, C., Gleixner, G., Habekost, M., Milcu, A., Partsch, S., Sabais, A. C. W., Scherber, C., Steinbeiss, S., Weigelt, A., Weisser, W. W., and Scheu, S.: Plant diversity effects on soil microorganisms support the singular hypothesis, Ecology, 91, 485-496, 2010.

Ekenler, M. and Tabatabai, M. A.: B-Glucosaminidase activity of soils: effect of cropping systems and its relationship to nitrogen mineralization, Biol. Fert. Soils, 36, 367-376, 2002.

Fierer, N., Schimel, J. P., and Holden, P. A.: Influence of dryingrewetting frequency on soil bacterial community structure, Microb. Ecol., 45, 63-71, 2003.

Franzluebbers, A. J.: Soil organic matter stratification ratio as an indicator of soil quality, Soil Till. Res., 66, 95-106, 2002.

Franzluebbers, A. J., Hons, F. M., and Zuberer, D. A.: Seasonal changes in soil microbial biomass and mineralizable $\mathrm{C}$ and $\mathrm{N}$ in wheat management systems, Soil Biol. Biochem., 26, 14691475, 1994. 
Franzluebbers, A. J., Hons, F. M., and Zuberer, D. A.: Soil organic carbon, microbial biomass, and mineralizable carbon and nitrogen in sorghum, Soil Sci. Soc. Am. J., 59, 460-466, 1995.

German, D. P., Weintraub, M. N., Grandy, A. S., Lauber, C. L., Rinkes, Z. L., and Allison, S. D.: Optimization of hydrolytic and oxidative enzyme methods for ecosystem studies, Soil Biol. Biochem., 43, 1387-1397, 2011.

Govaerts, B., Mezzalama, M., Unno, Y., Sayre, K. D., Luna-Guido, M., Vanherck, K., Dendooven, L., and Deckers, J.: Influence of tillage, residue management, and crop rotation on soil microbial biomass and catabolic diversity, Appl. Soil Ecol., 37, 18-30, 2007.

Grandy, A. S. and Robertson, G. P.: Land-use intensity effects on soil organic carbon accumulation rates and mechanisms, Ecosystems 10, 58-73, 2007.

Groffman, P., Driscoll, C., Fahey, T., Hardy, J., Fitzhugh, R., and Tierney, G.: Effects of mild winter freezing on soil nitrogen and carbon dynamics in a northern hardwood forest, Biogeochemistry, 56, 191-213, 2001.

Guckert, J. B., Carr, G. J., Johnson, T. D., Hamm, B. G., Davidson, D. H., Kumagai, Y.: Community analysis by Biolog: curve integrationf ro statistical analysis of activated slude microbial habitats, J. Microb. Meth., 27, 183-197, 1996.

Hamilton, S. K., Hussain, M. Z., Bhardwaj, A. K., Basso, B., and Robertson, G. P.: Comparative water use by maize, errennial crops, restored prairie, and poplar trees in the US Midwest, Environ. Res. Lett., 10, 064015, doi:10.1088/17489326/10/6/064015, 2015.

Hargreaves, S. K. and Hofmockel, K. S.: Physiological shifts in the microbial community drive changes in enzyme activity in a perennial agroecosystem, Biogeochemistry, 117, 67-79, 2014.

Hooper, D. U., Bignell, D. E., Brown, V. K., Brussard, L., Dangerfield, M. J., Wall, D. H., Wardle, D. A., Coleman, D. C., Giller, K. E., Lavelle, P., Van Der Putten, W. H., De Ruiter, P. C., Rusek, J., Silver, W. L., Tiedje, J. M., and Wolters, V.: Interactions between aboveground and belowground biodiversity in terrestrial ecosystems: Patterns, mechanisms, and feedbacks, BioScience, 50, 1049-1061, 2000.

Jiang, Y., Chen, C., Xu, Z., and Liu, Y.: Effects of single and mixed species forest ecosystems on diversity and function of soil microbial community in subtropical China, J. Soils Sediments, 12, 228-240, 2012.

Joergensen, R. G.: The fumigation-extraction method to estimate soil microbial biomass: Calibration of the $\mathrm{kEC}$ value, Soil Biol. Biochem., 28, 25-31, 1996.

Kabir, Z. and Koide, R. T.: The effect of dandelion or cover crop on mycorrhiza inoculum potential, soil agregation and yield of maize, Agr. Ecosyst. Environ., 78, 167-174, 2000.

Kallenbach, C. M., Grandy, A. S., Frey, S. D., and Diefendorf, A. F.: Microbial physiology and necromass regulate agricultural soil carbon accumulation, Soil Biol. Biochem., 91, 279-290, 2015.

KBS - Kellogg Biological Station Long-term Ecological Research: http://lter.kbs.msu.edu/, http://lter.kbs.msu.edu/datatables/75, last access: May 2015.

Kielak, A., Pijl, A. S., Van Veen, J. A., and Kowalchuk, G. A.: Differences in vegetation composition and plant species identity lead to only minor changes in soil-borne microbial communities in a former arable field, FEMS Microb. Ecol., 63, 372-382, 2008.
Korboulewsky, N., Perez, G., and Chauvat, M.: How tree diversity affects soil fauna diversity: A review, Soil Biol. Biochem., 94, 94-106, 2016.

Krupinsky, J. M., Bailey, K. L., McMullen, M. P., Gossen, B. D., and Turkington, T. K.: Managing plant disease risk in diversified cropping systems, Agron. J., 94, 198-209, 2002.

Lange, M., Eisenhauer, N., Sierra, C. A., Bessler, H., Engels, C., Griffiths, R. I., Mellado-Vázquez, P. G., Malik, A. A., Roy, J., Scheu, S., and Steinbeiss, S.: Plant diversity increases soil microbial activity and soil carbon storage, Nat. Comm., 6, 6707, doi:10.1038/ncomms7707, 2015.

Larkin, R. P.: Characterization of soil microbial communities under different potato cropping systems by microbial population dynamics, substrate utilization, and fatty acid profiles, Soil Biol. Biochem., 35, 1451-1466, 2003.

Lee, Y. B., Lorenz, N., Dick, L. K., and Dick, R. P.: Cold storage and pretreatment incubation effects on soil microbial properties, Soil Sci. Soc. Am. J., 71, 1299-1305, 2007.

Lodge, D. J.: Factors related to diversity of decomposer fungi in tropical forests, Biodivers. Conserv., 6, 681-688, 1997.

Lupwayi, N. Z., Rice, W. A., and Clayton, G. W.: Soil microbial diversity and community structure under wheat as influenced by tillage and crop rotation, Soil Biol. Biochem., 30, 1733-1741, 1998.

Magurran, A. E.: Measuring Biological Diversity, John Wiley \& Sons, Malden, MA, 2004.

Maire, V., Alvarez, G., Colombet, J., Comby, A., Despinasse, R., Dubreucq, E., Joly, M., Lehours, A.-C., Perrier, V., Shahzad, T., and Fontaine, S.: An unknown oxidative metabolism substantially contributes to soil $\mathrm{CO}_{2}$ emissions, Biogeosciences, 10 , 1155-1167, doi:10.5194/bg-10-1155-2013, 2013.

Mbuthia, L. W., Acosta-Martínez, V., DeBruyn, J., Schaeffer, S., Tyler, D., Odoi, E., Mpheshea, M., Walker, F., and Eash, N.: Long term tillage, cover crop, and fertilization effects on microbial community structure, activity: Implications for soil quality, Soil Biol. Biochem., 89, 24-34, 2015.

McDaniel, M. D., Grandy, A. S., Tiemann, L. K., and Weintraub, M. N.: Crop rotation complexity regulates the decomposition of high and low quality residues, Soil Biol. Biochem., 78, 243-254, 2014a.

McDaniel, M. D., Kaye, J. P., Kaye, M. W., and Bruns, M. A.: Climate change interactions affect soil carbon dioxide efflux and microbial functioning in a post-harvest forest, Oecologia, 174, 1437-1448, 2014b.

McDaniel, M. D., Tiemann, L. K., and Grandy, A. S.: Does agricultural crop diversity enhance soil microbial biomass and organic matter dynamics? a meta-analysis, Ecol. Appl., 24, 560 570, 2014c.

McDaniel, M. D., Wagner, R. J., Rollinson, C. R., Kimball, B. A., Kaye, M. W., and Kaye, J. P.: Microclimate and ecological threshold responses in a warming and wetting experiment following whole tree harvest, Theor. Appl. Climatol., 116, 287-299, 2014d.

McIntosh, A. C. S., Macdonald, S. E., and Quideau, S. A.: Linkages between the forest floor microbial community and resource heterogeneity within mature lodgepole pine forests, Soil Biol. Biochem., 63, 61-72, 2013. 
Mendes, I. C., Bandick, A. K., Dick, R. P., and Bottomley, P. J.: Microbial biomass and activities in soil aggregates affected by winter cover crops, Soil Sci. Soc. Am. J., 63, 873-881, 1999.

Mueller, K. E., Hobbie, S. E., Tilman, D., and Reich, P. B.: Effects of plant diversity, $\mathrm{N}$ fertilization, and elevated carbon dioxide on grassland soil $\mathrm{N}$ cycling in a long-term experiment, Global Change Biol., 19, 1249-1261, 2013.

Oksanen, J, Blanchet, F. G., Kindt, R., Legendre, P., Minchin, P. R., O'hara, R. B., Simpson, G. L., Solymos, P. M., Stevens, H., and Wagner, H.: Vegan: Community Ecology Package, R package version 2.3-3, https://CRAN.R-project.org/package=vegan, last access: 26 January 2016.

Paul, E. A., Harris, D., Collins, H. P., Schulthess, U., Robertson, G. P.: Evolution of $\mathrm{CO}_{2}$ and soil carbon dynamics in biologically managed, row-crop agroecosystems, Appl. Soil Ecol., 11, 53-65, 1999.

Peoples, M. S. and Koide, R. T.: Cosiderations in the storage of soil samples for enzyme activity analysis, Appl. Soil Ecol., 62, 98-102, 2012.

Peralta, A. L., Sun, Y., Brewer, M. S., McDaniel, M. D., and Lennon, J. T.: Crop diversity enhances disease suppressive potential in soils, Soil Biol. Biochem., in review, 2016.

Pietravalle, S. and Aspray, T. J.: $\mathrm{CO}_{2}$ and $\mathrm{O}_{2}$ respiration kinetics in hydrocarbon contaminated soils amended with organic carbon sources used to determine catabolic diversity, Environ. Poll., 176, 42-47, 2013.

Preston-Mafham, J., Boddy, L., and Randerson, P. F.: Analysis of microbial community functional diversity using sole-carbonsource utilisation profiles - a critique, FEMS Microbiol. Ecol., 42, 1-14, 2002.

Riedell, W. E., Pikul, J. L., Jaradat, A. A., and Schumacher, T. E.: Crop rotation and nitrogen input effects on soil fertility, maize mineral nutrition, yield, and seed composition, Agron. J., 101, 870-879, 2009.

Robertson, G. P., Coleman, D. C., Bledsoe, C. S., and Sollins, P.: Standard Soil Methods for Long-Term Ecological Research, Oxford University Press, New York, 1999.

Ryszkowski, L., Szajdak, L., and Karg, J.: Effects of continuous cropping of rye on soil biota and biochemistry, CRC CR Rev. Plant Sci.,17, 225-244, 1998.

Saiya-Cork, K. R., Sinsabaugh, R. L., and Zak, D. R.: The effects of long term nitrogen deposition on extracellular enzyme activity in an Acer saccharum forest soil, Soil Biol. Biochem., 34, 13091315, 2002.

Schimel, D. S., Coleman, D. C., and Horton, K. A.: Soil organic matter dynamics in paired rangeland and cropland toposequences in North Dakota, Geoderma, 36, 201-214, 1985.

Schimel, J. P., Scott, W. J., and Killham, K.: Changes in cytoplasmic carbon and nitrogen pools in a soil bacterium and a fungus in response to salt stress, Appl. Environ. Microbiol., 55, 1635-1637, 1989.

Schimel, J. P., Balser, T. C., and Wallenstein, M. D.: Microbial stress-response physiology and its implications for ecosystem function, Ecology, 88, 1386-94, 2007.

Schipanksi, M. E., Barbercheck, M., Douglas, M. R., Finney, D. M., Haider, K., Kaye, J. P., Kemanian, A. R., Mortensen, D. A., Ryan, M. R., Tooker, J., and White, C.: A framework for evaluating ecosystem services provided by cover crops in agroecosystems, Agr. Syst., 125, 12-22, 2014.
Smith, R. G., Gross, K. L., and Robertson, G. P.: Effects of crop diversity on agroecosystem function: Crop yield response, Ecosystems, 11, 355-366, 2008.

Stanford, G. and Smith, S. J.: Nitrogen mineralization potentials of soils, Soil Sci. Soc. Am. J., 36, 465-472, 1972.

Stephan, A., Meyer, A. H., and Schmid, B.: Plant diversity affects culturable soil bacteria in experimental grassland communities, J. Ecol., 88, 988-998, 2000.

Stirling, G. and Wilsey, B.: Empirical relationships between species richness, evenness, and proportional diversity, Am. Nat., 158, 286-299, 2001.

Strobel, B. W.: Influence of vegetation on low-molecular-weight carboxylic acids in soil solution - a review, Geoderma, 99, 169198, 2001.

Tibbett, M., Sanders, F. E., and Cairney, J. W. G.: Low-temperatureinduced changes in trehalose, mannitol and arabitol associated with enhanced tolerance to freezing in ectomycorrhizal basidiomycetes (Hebeloma spp.), Mycorrhiza, 12, 249-255, 2002.

Tiemann, L. K. and Billings, S. A.: Changes in variability of soil moisture alter microbial community $\mathrm{C}$ and $\mathrm{N}$ resource use, Soil Biol. Biochem., 43, 1837-1847, 2011.

Tiemann, L. K., Grandy, A. S., Atkinson, E. E., Marin-Spiotta, E., and McDaniel, M. D.: Crop rotational diversity enhances belowground communities and functions in an agroecosystem, Ecol. Lett., 18, 761-771, 2015.

Tilman, D., Knops, J., Wedin, D., Reich, P., Ritchie, M., and Siemann, E.: The influence of functional diversity and composition on ecosystem processes, Science, 277, 1300-1302, 1997.

Vance, E. D., Brookes, P. C., and Jenkinson, D. S.: An extraction method for measuring soil microbial biomass C, Soil Biol. Biochem., 19, 703-707, 1987.

Venter, Z. S., Jacobs, K., and Hawkins, H.-J.: The impact of crop rotation on soil microbial diversity: A meta-analysis, Pedobiologia, 59, 215-233, 2016.

Waldrop, M. P., Zak, D. R., Blackwood, C. B., Curtis, C. D., and Tilman, D.: Resource availability controls fungal diversity across a plant diversity gradient, Ecol. Lett., 9, 1127-1135, 2006.

Wardle, D. A.: A comparative assessment of factors which influence microbial biomass carbon and nitrogen levels in soil, Biol. Rev., 67, 321-358, 1992.

Wardle, D. A.: Is "sampling effect" a problem for experiments investigating biodiversity-ecosystem function relationships?, Oikos, 87, 403-407, 1999.

Wardle, D. A. and Ghani, A.: A critique of the microbial metabolic quotient $\left(q \mathrm{CO}_{2}\right)$ as a bioindicator of disturbance and ecosystem development, Soil Biol. Biochem., 12, 1601-1610, 1995.

Wardle, D. A., Yeates, G. W., Williamson, W., and Bonner, K. I.: The response of a three trophic level soil food web to the identity and diversity of plant species and functional groups, Oikos, 102, 45-56, 2003.

Williams, S. M. and Weil, R. R.: Crop cover root channels may alleviate soil compaction effects on soybean crop, Soil Sci. Soc. Am. J., 68, 1403-1409, 2004.

Wu, T., Chellemi, D., Graham, J., Martin, K., and Rosskopf, E.: Comparison of soil bacterial communities under diverse agricultural land management and crop production practices, Microb. Ecol., 55, 293-310, 2008.

Xuan, D., Guong, V., Rosling, A., Alström, S., Chai, B., and Högberg, N.: Different crop rotation systems as drivers of change 
in soil bacterial community structure and yield of rice, Oryza sativa, Biol. Fert. Soils, 48, 217-225, 2012.

Zak, D. R., Holmes, W. E., White, D. C., Peacock, A. D., and Tilman, D.: Plant diversity, soil microbial communities, and ecosystem function: Are there any links?, Ecology, 84, 20422050, 2003.
Zhou, X., Wu, H., Koetz, E., Xu, Z., and Chen, C.: Soil labile carbon and nitrogen pools and microbial metabolic diversity under winter crops in an arid environment, Appl. Soil Ecol., 53, 49-55, 2012.

Zuur, A. F., Ieno, E. N., and Elphick, C. S.: A protocol for data exploration to avoid common statistical problems, Meth. Ecol. Evol., 1, 3-14, 2010. 